\title{
NON CONFORMITY TO NORMS
}

WHY DO STATES PROLIFERATE IN OPPOSITION TO WELL ESTABLISHED AND POWERFUL NON-PROLIFERATION NORMS?

By

James Te Rangihiwinui Latimer Kerr

A Thesis submitted to the Victoria University of Wellington in Partial Fulfilment of the Requirements for the Degree of Master of International Relations

Victoria University Wellington 
To my beloved wife Jessica 


\section{Abstract}

Nine countries currently have nuclear weapons and of these only three have acquired them in the past 40 years. The primary reason for this has been the establishment of a powerful nuclear non-proliferation regime and its associated norms. The powerful influence of both the regime and the resulting norms on state behaviour is unquestionable. However a limited amount of state proliferation continues and some states' behaviour suggests that they either reject, or believe that they are outside of the influence of the regime and its norms.

My study is looking at the problem of non-conformity to the non-proliferation norm to see why it occurs. The issue is specifically a nuclear one however non-conformity to norms has wider implications in the study of international relations (IR). Regimes and norms clearly do not exist in a vacuum but operate within an international social environment. This nuclear issue remains a central consideration for state foreign policy and hence has justified extensive examination in the field of IR. The intellectually and ethically complex issues that surround access to this technology were acknowledged from its devastating baptism in Hiroshima and Nagasaki.

International regulation was seen as the most appropriate form of control of nuclear weapons. This was in part due to the potential consequence of the misuse and the impact of accidents transcending national boundaries. This ultimate destructive capability has only been in the hands of a few states and the dissemination and control of this capability has been contentious from the day it was first used. Initially its power came from its potential to completely dominate militarily. As soon as the second country gained the same capability it became a lot more complicated. The destructive capability of nuclear weapons is such that any future war that saw their use could result in the annihilation of the human species. The Cold War and its extreme vertical nuclear proliferation actualised this fear.

Nuclear technologies dual purpose functionality, of both peaceful power generation and the creation of a military nuclear capability make for a complex situation. There is an obvious power imbalance between the nuclear haves and have-nots and a self protective desire to stop or at least limit the number of countries attempting to join the 'nuclear club'. 
Both realism and neo-liberal institutionalism are able to explain, in part, conformity and non conformity to regimes and their associated norms within today's social environment. In this study I will use a social constructivist approach, which is based on the outcomes of persuasion, identification and social conformity, to see if it can add to the current explanations of state nuclear proliferation. 


\section{Acknowledgements}

I would like to thank, my supervisor Esref Aksu for his patient and wise console from conception until submission. The research staff at Victoria University Library for their great natured and professional advice and assistance. Justin Kerr and Jacqui Latimer for their tireless efforts in proof reading and re reading my work. Most importantly Jessica, Maddalena, Matilda and Ynes for their loving support throughout this process. 


\section{Table of Contents}

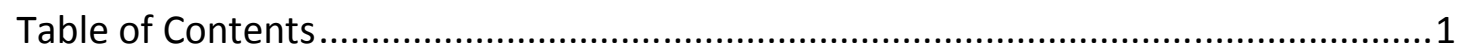

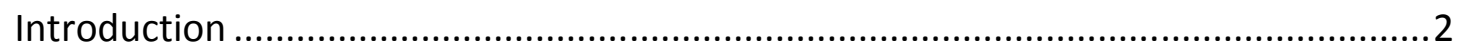

Nuclear Proliferation Expectations Versus Reality ............................................... 5

The NPT and the wider non-proliferation regime................................................ 5

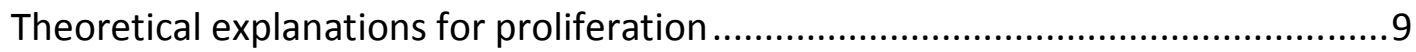

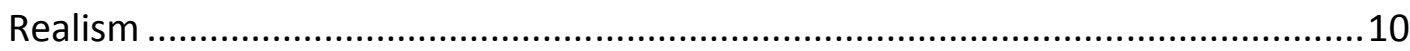

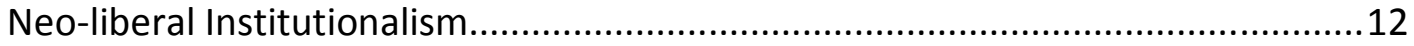

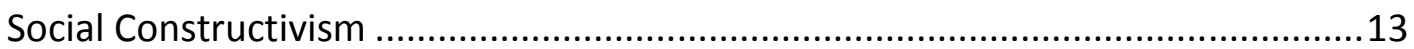

Iran: The International Community's Mixed Messages ............................................21

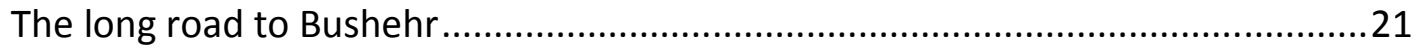

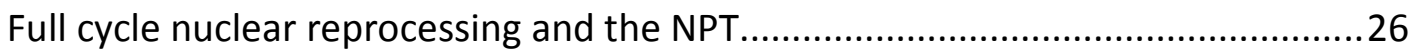

The proliferation decision making of the elites ..................................................32

Israel: Special Friendships to Maintain a Nuclear Monopoly .....................................36

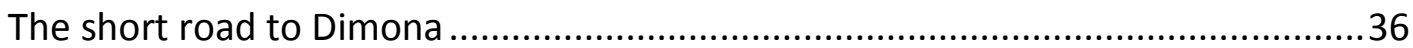

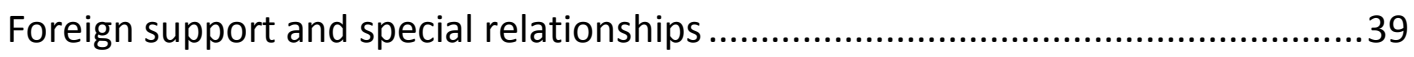

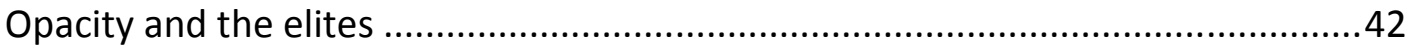

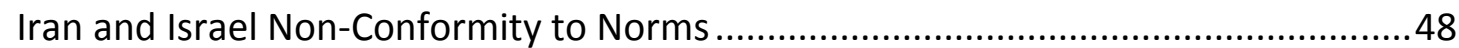

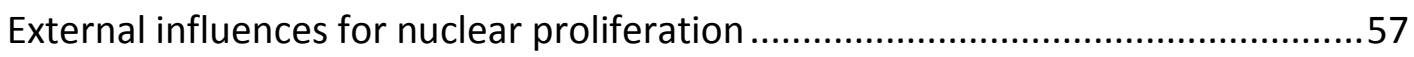

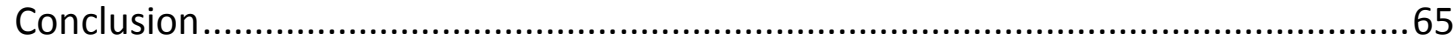

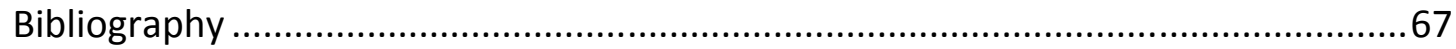




\section{Introduction}

Nine countries currently have nuclear weapons and of these only three have acquired them in the past 40 years. The primary reason for this has been the establishment of a powerful nuclear non-proliferation regime and its associated norms. ${ }^{1}$ The powerful influence of both the regime and the resulting norms on state behaviour is unquestionable. However a limited amount of state proliferation continues and some states' behaviour suggests that they either reject, or believe that they are outside of the influence of the regime and its norms.

My study is looking at the problem of non-conformity to the non-proliferation norm to see why it occurs. The issue is specifically a nuclear one however non-conformity to norms has wider implications in the study of international relations (IR). Regimes and norms clearly do not exist in a vacuum but operate within an international social environment. ${ }^{2}$ This nuclear issue remains a central consideration for state foreign policy and hence has justified extensive examination in the field of IR. The intellectually and ethically complex issues that surround access to this technology were acknowledged from its devastating baptism in Hiroshima and Nagasaki.

International regulation was seen as the most appropriate form of control of nuclear weapons. This was in part due to the potential consequence of the misuse and the impact of accidents transcending national boundaries. This ultimate destructive capability has only been in the hands of a few states and the dissemination and control of this capability has been contentious from the day it was first used. Initially its power came from its potential to completely dominate militarily. As soon as the second country gained the same capability it became a lot more complicated. The destructive capability of nuclear weapons is such that any future war that saw their use could result in the annihilation of the human species. The Cold War and its extreme vertical nuclear proliferation actualised this fear.

\footnotetext{
${ }^{1}$ Definition of regime is "principals, norms, rules and decision-making procedures around which actors expectations converge in a given issue area" taken from SD Krasner, "Structural Causes and Regime Consequences: Regimes as Intervening Variables," International Organization (1982). ${ }^{2}$ MR Rublee, "Taking Stock of the Nuclear Nonproliferation Regime: Using Social Psychology to Understand Regime Effectiveness," International Studies Review 10, no. 3 (2008). Pgs 424-6.
} 
Nuclear technologies dual purpose functionality, of both peaceful power generation and the creation of a military nuclear capability make for a complex situation. There is an obvious power imbalance between the nuclear haves and have-nots and a self protective desire to stop or at least limit the number of countries attempting to join the 'nuclear club'.

Both realism and neo-liberal institutionalism are able to explain, in part, conformity and non conformity to regimes and their associated norms within today's social environment. In this study I will use a social constructivist approach, which is based on the outcomes of persuasion, identification and social conformity, to see if it can add to the current explanations of state nuclear proliferation.

As part of this study I have selected two case studies; Iran and Israel. I have selected these countries because they are both to varying degrees pariahs in the international system. By this I mean that they are consistently presented as the exception to international norms and because of this they are the state actors that directly challenge these norms. Both counties have over time continuously and consistently tested the intent and purpose of the non-proliferation regime. These countries have, by their actions, also exposed the double standards within the regime and the broader international environment. These double standards manifest themselves in the inconsistent manner in which different countries are treated by members of the international community. What purports to be a uniformly applied, transparent and fair system is in reality, as might be expected, one that is implemented in a highly subjective manner. This is based on the manifestly uneven state power relationships in favour of the nuclear haves over the have-nots.

The manner in which these two countries have gone about proliferation has been different, their approaches have changed over time, and their motives for doing so have also changed. The fluid international environment in which they both operate has also changed which has in turn affected some of their reasons for proliferation. 
My thesis is divided into four sections; the first section presents an overview of the non-proliferation regime and three theoretical explanations for it. The three approaches used in my study are; realist, neo-liberal institutionalist, and constructivist to see how they explain proliferation. The second and third sections are my case studies on Iran and Israel respectively. In these case studies my focus is the process by which the states have or are in the process of acquiring nuclear weapons and the rationale behind this process. In the fourth section I have applied a social constructivist approach to these case studies.

The conclusion outlines why I believe that a constructivist framework offers useful additional tools to explain state proliferation. This approach allows proliferation to be examined by looking at the state rationale for the decision not to conform to the non-proliferation norms and the regime itself. 


\section{Nuclear Proliferation Expectations Versus Reality}

The purpose of this section is twofold; firstly to present a descriptive outline of the non-proliferation regime, defining the different elements that it consists of. Secondly to examine three dominant IR paradigms and explain how they attempt to explain proliferation and non-proliferation. The three approaches in this paper are realism, neo-liberal institutionalism and a social constructivist theory that focuses on the international social environment, norms and regimes and how they interrelate to shape state behaviour.

\section{The NPT and the wider non-proliferation regime}

The non-proliferation regime consists of multiple elements, but it is the Nuclear Non-Proliferation Treaty (NPT) that is at the core of this regime. ${ }^{3}$ This section will present an overview of the NPT as well as explaining the relationship it has to the other elements of the regime.

The NPT was presented for signing in 1968 and entered into force in 1970. It is an 11 article treaty which is currently signed by 189 of the 192 recognised sovereign states of the world. ${ }^{4}$ Israel, India and Pakistan are the three states that have never been signatories and North Korea officially withdrew from it in 2003. The NPT is an aspirational treaty in that it not only sets out how to operate in the here and now but also includes in article VI, a commitment to ultimately work towards a nuclear weapon free world.

The NPT has effectively categorised states into their current (at the time of the original signing of the treaty) nuclear capabilities and laid down a very basic framework for the movement between these categories. The NPT was constructed with a glass ceiling and it is this ceiling and the inherent difficulty in measuring

\footnotetext{
${ }^{3}$ Treaty on the Non-Proliferation of Nuclear Weapons, (22 April 1970).

${ }^{4}$ NPT numbers from P Margulies, Nuclear Nonproliferation, Global Issues (facts on File, 2008). Pgs 231-4.
} 
state's proximity to it that is the crux of the ongoing nuclear issue. The NPT's cut off for allowing state possession of nuclear weapons was that they had to be tested prior to the first of January 1967.

The Treaty itself does not have any implicit mechanism for its own enforcement and does not detail any possible sanctions that can be applied to states that violate it. ${ }^{5}$ Violations of the NPT are dealt with by the United Nations Security Council (UNSC) which has the mandate to enforce sanctions as well as authorise military action against states. The UNSC is dominated by its five permanent member states (the P5) which were originally selected as a result of the outcome of World War II. ${ }^{6}$ They have all subsequently become nuclear weapon states. All of the P5 hold veto power for any UNSC resolution, which means a negative vote from any one of the P5 will result in a resolution not being passed. The dominance of nuclear weapon states on the UNSC could be seen as undermining the non-proliferation regime. When the P5 states were initially chosen in 1946 the US was the only one of them to possess nuclear weapons. ${ }^{7}$

The NPT is reviewed every five years and was originally drafted to last for 25 years. In 1995 after two extensions, it was agreed to extend it indefinitely. As is common practice with most international treaties these five yearly reviews provide an opportunity for signatories to negotiate interpretive as well as compliance issues. The treaty was the culmination of previous failed attempts to contain the growing fear of an increasingly nuclear world. The use of nuclear weapons by the US against Japan had shown the world their immensely destructive capabilities. This motivated the international community to regulate access to them. The subsequent vertical nuclear proliferation of the Cold War and the fear that horizontal nuclear proliferation would follow added to the impetus for regulation. Events like the Cuban Missile crisis of 1962 only emphasised the need for more formal controls which the NPT was able to provide. Today the NPT stands alone as the most

\footnotetext{
${ }^{5}$ KC Bailey, Strengthening Nuclear Nonproliferation (Westview Press, 1993). Pg 14.

${ }^{6}$ The P 5 states are; The United States, Russia, China, France and The United Kingdom.

${ }^{7}$ Bailey, Strengthening Nuclear Nonproliferation. Pg 12.
} 
internationally supported multilateral treaty dealing with the containment of any form of armaments in world history. ${ }^{8}$ The NPT has been the catalyst for the establishment of the other non-proliferation components that make up the regime.

The International Atomic Energy Agency (IAEA) is the body that is charged with inspecting national nuclear programmes under the NPT. Its role is to independently verify that what states profess to be occurring within their nuclear programmes is in fact the case. The way in which the agency does this is referred to as the implementation of safeguards. There are two main safeguards. Firstly states are required to declare all of their nuclear installations so they can be inspected by the IAEA. ${ }^{9}$ Secondly signatories must keep detailed records so that all nuclear fissile material can be accounted for. This is to stop the diversion of this material to other unsanctioned nuclear (weapon) programmes. ${ }^{10}$ The IAEA is tasked with referring states that do not comply with the safeguards to the UNSC which is mandated to administer disciplinary proceedings. The most common form this takes is economic sanctions against countries, but could include military action. These disciplinary proceedings can only be brought against countries that are signatories of the NPT which leaves out Israel, India, Pakistan and since 2003 the Democratic People's Republic of Korea (DPRK). The IAEA's independence and neutrality are essential for it to perform these functions. The IAEA has a finite budget and personnel which limits its ability to be abreast of every state's nuclear programmes. The biggest limitation of the IAEA is that its role is focused on declared nuclear facilities and the verification that what is being stated as happening is in fact occurring. They do not have the power to conduct snap inspections, they have to pre schedule any inspections which results in them having to operate largely on trust.

\footnotetext{
${ }^{8}$ Rauf, The strengthened NPT review process: legal and diplomatic considerations. Chapter 3 in C Ungerer and M Hanson, The Politics of Nuclear Non-Proliferation (Allen \& Unwin in association with the Dept. of International Relations, RSPAS, St. Leonards, NSW, Australia, 2001).

${ }^{9}$ The IAEA has no organic intelligence branch but relies on a mixture of open source research, reports from state intelligence agencies (this is often a process of informing on your neighbour or enemy) and comparative studies from previous inspections. Recent improvements in commercially available satellite photography are also being utilised.

${ }^{10}$ I Bellany, Curbing the Spread of Nuclear Weapons (Manchester University Press, 2005). Pgs 76-78.
} 
Article VII of the NPT allows for the establishment of regional Nuclear Weapon Free Zones (NWFZ). These currently exist in The South Pacific, Africa, Latin America including the Caribbean and Central Asia. The NWFZ act as another layer of the nonproliferation regime and hence strengthen its associated norms. The Comprehensive Test Ban Treaty (CTBT) was adopted by the United Nations General Assembly (UNGA) in 1996. It was ratified by Russia in 2000, however it has never been able to get US Senate approval, so is still remains a work in progress. ${ }^{11}$

The establishment of export control groups was an attempt to firstly define what sensitive nuclear equipment was and then regulate its sale. The Nuclear Suppliers Group (NSG) and the Missile Technology Control Regime (MTCR) are both examples of attempts to put the aims of the NPT ahead of financial profit. The sale of nuclear and missile technology is very profitable and the intent behind these two groups is to put checks and balances in place as tools for the voluntary regulation of as much of this market as possible. The emphasis is on dual use technology, which is technology that can have applications for both nuclear power and nuclear weapon programmes. The establishment of security assurances from more powerful countries with their 'nuclear umbrellas' have played a part in removing some of the security motivations for states to develop their own nuclear programmes. This was the cornerstone of Cold War deterrence strategy and effectively divided the world in two as an attack on a state within the umbrella was to be treated the same as an attack on the US or the USSR and retaliation was to be expected.

The final component of the regime is the bilateral nuclear disarmament agreements between the US and Russia, the two countries with by far the most nuclear weapons. ${ }^{12}$ Strategic Arms Reduction Talks (START I and II) and the Strategic Offensive Reduction Treaty (SORT) have both been successful in reducing both the number of warheads each state has as well as reducing the level of operational preparedness at which these weapons are held.

\footnotetext{
${ }^{11}$ Margulies, Nuclear Nonproliferation. Pg 32.

${ }^{12}$ These agreements were entered into with the USSR and after its breakup all of its nuclear weapons were concentrated in Russia.
} 
The nuclear non-proliferation regime is centred on the NPT, however, it is more than just the NPT. It is the combination of a network of multilateral and bilateral agreements, structures and relationships which also include the IAEA, the Comprehensive Test Ban Treaty (CTBT), Nuclear Weapon Free Zones (NWFZ) and the Nuclear Suppliers Group. ${ }^{13}$ It is the combined effect of these that make up the nonproliferation regime, and establish and project the non-proliferation norms. The network includes a mixture of treaties which are codified into international law, agencies that inform on compliance, institutions like the UNSC that adjudicate and enforce compliance, as well as voluntary commitments like the NWFZ and NSG. The regime is fluid but over time, and especially since the establishment of the NPT, it has got stronger and expanded its sphere of influence. Although not all elements of the regime always align towards a single objective, they are all focused in one direction which is the regulation of nuclear technology. This is achieved through the provision of mutual assistance to facilitate signatory states in acquiring nuclear power generation if they want it. The by product of this regulated environment is the close control of all nuclear technology especially that which is able to be used for nuclear weapon production. This regime and the associated norms have a symbiotic relationship, shaping, directing and reinforcing but as well have the potential to undermine each other. The second part of this section will look at how different IR theories attempt to explain non-proliferation and proliferation.

\section{Theoretical explanations for proliferation}

Different IR theories attempt to explain nuclear proliferation and non-proliferation. This section will describe three different such theories. The first two, realist and neo-liberal institutionalism, I believe, offer only part of the required explanation for these events. The third paradigm comes from the social constructivist school. It attempts to explain state nuclear restraint as being a consequence of adherence to non-proliferation norms.

\footnotetext{
${ }^{13}$ MR Rublee, Nonproliferation Norms: Why States Choose Nuclear Restraint (Univ of Georgia Press, 2009). Pg 38.
} 
In any analysis of proliferation and non-proliferation it is important to deconstruct the notion of a state as a homogeneous entity for decision making. This is because it is almost always a small group of elites that make the decision to acquire a nuclear capability. Because this is the case these elites, or decision makers, can be persuaded and influenced by other elements. These influences can come from internal or external sources or a combination of the two. As regimes evolve, through the creation of treaties and agreements they create norms of behaviour that either reinforce the regime or undermine it. Limited norms can exist prior to their codification within a regime and are either strengthened or weakened by the evolving regime. ${ }^{14}$ The three theoretical approaches each provide differing perspectives on the role and utility of norms, regimes and the international social environment. These differences come from the way in which each views the role and motivations of the state operating within the international environment.

\section{Realism}

"Our bombs are not just directed to the east but in all directions". ${ }^{15}$

The realist perspective has predicted a continuing increase in the number of states that will acquire nuclear weapons. ${ }^{16}$ This is based on the perception that a states security situation will be improved by the possession of nuclear weapons. The premise is that the deterrent effect that comes from the possession of nuclear weapons cannot be matched by the possession of conventional weapons. The "state of anarchy" in which states operate and their primary motivation, self help, will lead states to want to acquire whatever it deems as necessary to ensure its survival. Because today's friends can be tomorrow's enemies it is not prudent to rely on security guarantees provided by other states for one's long term security. It is

\footnotetext{
${ }^{14}$ Rublee, "Taking Stock of the Nuclear Nonproliferation Regime: Using Social Psychology to Understand Regime Effectiveness."Pg 424-426.

${ }^{15}$ Quote attributed to Charles De Gaulle.

${ }^{16}$ I am providing an overview of realism which is situated in generalist terms so neo-realism could be used interchangeably.
} 
therefore in the best interest of all states to attempt to acquire nuclear weapons. The only thing that would stop states doing so would be supply side issues like the lack of technology or access to raw materials. States that have the internal capability to manufacture nuclear weapons are not looking after their own best interests if they don't do it and should assume everyone else who can, will be doing so. ${ }^{17}$

The non-proliferation regime and especially the NPT could only be considered useful if it facilitated access to technology not currently possessed. Once that technology is acquired with the associated expertise required to operate it, the realist view is that you should leave the NPT and build nuclear weapons. Waltz, goes even further by emphasising the utility of a second strike capability and how the possession of one will almost rule out the possibility of other states attacking you. ${ }^{18}$

The strength of the realist theory lays in its ability to justify proliferation. In fact, it sees it as the only logical outcome for a state that has the technological capability to achieve it. The possession of this capability will also result in the state being taken seriously within the international environment of anarchy. This view has been criticised because it does not reflect what has actually happened. The number of states with nuclear weapons is still low and over the past 40 years only three states have acquired and maintained nuclear weapons. Many more have actually destroyed them or cancelled their nuclear weapon programmes. What the realist perspective does do, according to Hymans, is to correctly see the supply side as a central part of proliferation. However, at the same time it fails to explain a continued lack on the demand side. ${ }^{19}$

Sagan argues that it is the absolute finality of the consequence of the use of nuclear weapons that has caused states to move them to a level above that of conventional military weapons. By doing so, they have effectively been removed, by most, from

\footnotetext{
${ }^{17}$ Hymans, Theories of nuclear proliferation the state of the field. Pg 24 in P Lavoy, Nuclear Weapons Proliferation in the Next Decade (Routledge, 2007).

${ }^{18}$ SD Sagan and KN Waltz, The Spread of Nuclear Weapons: A Debate Renewed, 2nd updated from 1995 first edition ed. (W. W. Norton \& Company, 2003). Pg 13.

${ }^{19}$ Hymans, Theories of nuclear proliferation the state of the field. Pg 26 in Lavoy, Nuclear Weapons Proliferation in the Next Decade.
} 
the theoretical list of viable options available for state defence. This would explain the continued realist stance taken by most militaries with regards to conventional weapons. The nuclear option is thus rejected, Sagan suggests, on moral grounds, or on the belief that it lowers the state's security by making it a target. ${ }^{20}$ It is widely agreed that realists consistently over predict future proliferation and find it difficult to explain the success of non-proliferation when it goes against their perception of what is in a state's best interest.

\section{Neo-liberal Institutionalism}

This paradigm accepts much of the realist argument however it adds a further dimension to the debate. It does not take the utility of nuclear weapons possession as a given but rather argues that states undertake a complex cost benefit analysis as part of their decision making process. This analysis takes place on multiple levels; the international, domestic and the individual. Realists would regard this analysis as pointless because they see nuclear weapons as being the ultimate security guarantee for a state and their utility lies simply in the possessing of them.

This distinction is critical because while both see interest as fixed they have different ideas about how those preferences can best be obtained and attach different weight to absolute as opposed to relative gains.

The cost benefit calculations which are being carried out by states on all three levels acknowledge that they are interrelated and each can influence the other. The reactions of others, be they other states, domestic elements or individuals, matter and these can be considerations for all interest groups to varying degrees depending on the issue. This is because all groups want to pursue what is best for their perception of self interest but this itself is partly defined by what others groups are doing and how they define their self interest. Often this cost benefit calculation is

\footnotetext{
${ }^{20}$ Sagan "Realist Perspectives on Ethical Norms and Weapons of Mass Destruction" in SH Hashmi and $\mathrm{S}$ Lee, Ethics and Weapons of Mass Destruction Religious and Secular Perspectives (Cambridge University Press, 2004).
} 
focused on national economic factors, which is partially why economic sanctions are used as punishment for transgression within this fluid environment.

This theory also offers a partial explanation of why both Japan and Germany have not proliferated even though they both have the capability. Both countries have derived economic advantage by not putting the money into nuclear weapons programmes. The result of this decision has been an increase in their respective status internationally in ways that would not have been possible had they chosen to proliferate.

Summarising the two previous positions, from a realist perspective, the regime is at best a tool that potential proliferators can use in order to proliferate. For the neoliberal institutionalist the regime can affect the cost benefit calculations that states make about whether to proliferate or not and the stronger the regime is the more likely their decision will be not to proliferate. This is not because they are convinced that proliferation itself is a bad thing rather that in the current situation the cost of doing so outweighs the benefits. Before moving to the third paradigm, social constructivism, it is important to confirm that for these paradigms it is not a case of either or but a mixture of them all that provides the most comprehensive explanations for nuclear proliferation.

\section{Social Constructivism}

"The single most important factor in producing this success has been the nonproliferation norm established by the NPT and the incentives for remaining nonnuclear that the NPT helped initiate."21

The final paradigm comes from the social constructivist school. Constructivist view power as being more than just kinetic, that is the result of military dominance, and see it as being the result of process and not just structure. Maria Rublee has developed a framework that comes from this constructivist school and borrows

\footnotetext{
${ }^{21}$ G Bunn, "The Nuclear Nonproliferation Treaty: History and Current Problems," Arms Control Today 33 , no. 10 (2003). Pg 6.
} 
from well-established social psychology theories to do so. ${ }^{22}$ Her framework is outlined in her book "Non-Proliferation Norms, Why States Choose Nuclear Restraint". She uses her framework to explain why states have shown restraint in the acquisition of nuclear weapons. ${ }^{23}$ She tested her framework against states that have started to develop nuclear weapons and for a variety of reasons stopped these programmes. Her central argument is that the actions of these states, not to proliferate, cannot be sufficiently explained by the two previous theories that dominated IR. It is the inclusion of the constructivist paradigm that gives a more comprehensive explanation for what has occurred.

To understand Rublee's framework it is essential to understand how she has defined the international social environment and the non-proliferation regime that has evolved within it. The international social environment is the totality of competing and complementary regimes which covers a diversity of issues; security, human rights, international law and economics for example. It is essentially the fluid interplay of the domestic and the international. It can be looked at from a specific angle and for the purposes of this study, this angle is how it relates to the nuclear non-proliferation regime. A regime establishes norms and norms shape regimes depending on how these norms are interpreted. I am focusing on the manner in which these norms are transmitted to and by states, and the subsequent acceptance or rejection of them by states. Regimes can often be in conflict with each other and the acceptance of one can require the rejection or a limited acceptance of others. State's decisions can and do change depending on their domestic situation vis a vis the broader international social environment and the desire to place a greater emphasis on one regime over that of another. Rublee uses five countries as case studies to test her framework. Japan, Egypt, Libya, Sweden and Germany all of which started down the path of nuclear proliferation but for different reasons stopped. I will draw on these case studies as required. I will now

\footnotetext{
${ }^{22}$ In this study I use 'constructivism' interchangeably with 'Rublee's framework'. I acknowledge that constructivism is broader that Rublee's framework however I am comparing it to realism and neoliberal institutionalism not other forms of constructivism.

${ }^{23}$ Rublee, Nonproliferation Norms: Why States Choose Nuclear Restraint. This book is the central text for my thesis.
} 
explain how these norms are transmitted, processed and what defines their potency.

Norm transmission is the different way in which the combined elements of the regime influence state decision makers. The first is by descriptive norms, which means two things, firstly that what states actually do is as important as what they say they will do. Secondly, states watch the actions of other states and base their actions in part on this. The result of this is that in complex situations appropriate state behaviour is defined by the collective actions of those that the state identifies with. ${ }^{24}$ Injunctive norms are prescriptive of proper or improper behaviour. The decision to choose one over the other will have consequences such as economic sanctions or the transfer of nuclear power technology. ${ }^{25}$ Subjective norms are the interpretation of descriptive and injunctive norms by decision makers as well as the absorption of related messages from the international community. They are the decision maker's interpretation of what others believe about a norm. ${ }^{26}$

There are numerous norms that states are subject to and the way in which these norms are accepted or rejected is the result of how they are processed. ${ }^{27}$ There are three ways this happens; linking, activation and consistency.

Linking is when an international norm is connected to well established pre-existing internal values. Being a responsible member of the international community is normally seen by states as being part of their internalised values. Non-proliferation is widely seen as a requirement of this therefore non-proliferation has been linked to what it is to be a responsible member of the international community. To proliferate is to break the connection with this specific value and to do so will have consequences. $^{28}$

\footnotetext{
${ }^{24}$ Ibid. Pg 40.

${ }^{25}$ Ibid. Pg 40-41.

${ }^{26}$ Ibid. Pg 41-42

27 - - , "Taking Stock of the Nuclear Nonproliferation Regime: Using Social Psychology to Understand Regime Effectiveness."Pg 426

${ }^{28}$ - - - Nonproliferation Norms: Why States Choose Nuclear Restraint. Pg 44-45.
} 
Activation is when a norm has been highlighted or made the focal point for decision making. Descriptive, injunctive and subjective norms can often contradict or compete with one another and it is the activation of one norm over another that can make a state decide in favour of it. ${ }^{29}$

Consistency refers to past behaviour being the best predictor of future behaviour. Once a state makes a decision there is an internalisation of this decision which has a flow on effect. Proliferation which might have initially been a military decision by a small group of decision makers will then have an impact on diplomats, exporters, bankers as well as the wider population. ${ }^{30}$

The third element of the norm is its potency, which is how effective it is at influencing a state's decision making. Potency is broken into three parts uncertainty, similarity and conflict.

Uncertainty refers to, not knowing the impact, both positive and negative, that a specific decision made by a state will have on it, and how others see it. The greater the level of uncertainty that exists, the more likely the decision makers are to accept group or outside group influence in their decision making on the issue. In complex decisions like those concerning whether to proliferate or not, domestic considerations come into conflict with international norms and it is at these times, that outside assistance is often sought to assist in the decision making process. ${ }^{31}$

Similarity refers to a norm being more potent if its transmitter is something or someone with whom the recipient can or wishes to identify with in the future. ${ }^{32}$

And lastly conflict, which can have the effect of decreasing the potency of the norm that is being transmitted because of actual or expected conflict. This is because of the tendency to close ranks and look inwards during conflict. ${ }^{33}$ The conflict could be

\footnotetext{
${ }^{29}$ Ibid. Pg 45-46.

${ }^{30}$ Ibid. Pg 46-49.

${ }^{31}$ Ibid. Pg 49.

${ }^{32}$ Ibid. Pg 49-50.

${ }^{33}$ Ibid. Pg 50.
} 
within a state, a civil war for example, but more often refers to one that comes from without. Iran pursuing nuclear weapons in 1985 during the Iran/Iraq war provide a clear example of this from my case study. This proliferation desire was reinforced after George Bush's 2003 speech which labelled Iran as part of the "axis of evil". The expectation of inevitable conflict between Iran and the US resulted in an increased emphasis being placed on proliferation by Iran's elites. ${ }^{34}$ When states face an existential threat, the result can be the subjugation of the norm in favour of proliferation. Israel can also be used to emphasise this point. Ongoing internal conflict with the Palestinians and more importantly existential threats from neighbouring Arab states have reaffirmed the initial desire to proliferate by its decision makers.

The transmission, processing and potency of norms and each of their three sub parts allows one to understand the mechanics behind the adoption or rejection of non-proliferation norms. They allow analysis of the non-proliferation norms and how they operate within the international social environment. The final part of Rublee's framework expands the state decision about whether to proliferate or not to proliferate and attempts to explain why that decision has been made. The why is critical because it enables assessment of the strength of the norm and it identifies the way in which the decision makers have accepted or rejected it. Rublee's three outcomes or state rationale behind the acceptance or rejection of the norm are; persuasion, social conformity and identity.

Persuasion describes the behaviour that results from a genuine transfer of preferences. "I now see that $\mathrm{X}$ is better than $\mathrm{Y}$ ". ${ }^{35} \mathrm{It}$ is the internalisation of a decision which is the result of a genuine change of preference.

\footnotetext{
${ }^{34} \mathrm{~T}$ Delpech, Iran and the Bomb: The Abdication of International Responsibility, trans. From French by Ros Schwartz (C. Hurst \& Co. London, 2009). Pg 7-24, outlines what Delpech calls "Iran's indisputable military nuclear ambition" and the key triggers for it to be re emphasised.

${ }^{35}$ A.I. Johnston, "Treating International Institutions as Social Environments," International Studies Quarterly 45, no. 4 (2001).Pg 496-499.
} 
Identification describes behaviour that is the result of the desire to follow, or the habit of following the actions of an important ally. This is the most flexible of the three as a decision to change can be the result of the change of preference of ally or a change of preference as to who that ally actually is. There does not need to be any internalisation of a state's position in this case. However as discussed above norm processing and the role of consistency will result in the establishment of the necessary apparatus to support this decision. The length of time a state holds the same position, regardless of why, will play a large part in it maintaining that position. This is because the resulting institutionalisation and/or bureaucratisation of the policy can work against change through systemic inertia.

Social conformity is behaviour that is the result of the desire to maximise social benefits and/or minimise social costs without changing underlying preferences. "I think that $\mathrm{Y}$ is better (or I like $\mathrm{Y}$ more) but since everyone else is doing $\mathrm{X} I$ will do $\mathrm{X}$ so as to not rock the boat". ${ }^{36}$ Rublee emphasises the importance of differentiating between persuasion and social conformity because many states that don't proliferate as a result of social conformity are in effect "nuclear hedging". ${ }^{37}$ Although they are not currently in possession of nuclear weapons some states have a plan to acquire them quickly if the international situation changes. South Korea and Sweden are examples of this. They have the technological capability, domestic nuclear expertise as well as the finances to internally develop nuclear weapons. ${ }^{38}$ There is a fear that Iran will have the same option available to it if they acquire full cycle nuclear reprocessing capability as part of their nuclear power programme. Social conformity has clear linkages to neo-liberal institutionalist explanations for non-proliferation and the fluid nature of what is in the best interests of states.

\footnotetext{
${ }^{36}$ Ibid.Pg 499-506.

${ }^{37}$ Rublee, Nonproliferation Norms: Why States Choose Nuclear Restraint. Pg 18.

${ }^{38}$ AE Levite, "Never Say Never Again: Nuclear Reversal Revisited," International Security 27, no. 3 (2003). Pg 65. Explains how these countries although supportive of the regime still keep the option open. Also see SD Sagan, "Why Do States Build Nuclear Weapons?: Three Models in Search of a Bomb," International Security (1996). For an explanation of how the NPT allows this happen through its three month stand down period.
} 
The distinction between these three types of conformity can also be used to explain and define the different positions of interest groups within states. It is often the interplay of these interest groups as they each compete for their view to be the dominant one of the state that is crucial in determining a state's nuclear policy. In the case of both Israel and Iran it is the exclusion of alternative points of view which is notable. All decisions regarding proliferation have always been held in the hands of an elite few.

Attempts have been made to explain proliferation as being a consequence of a specific state's sense of being outside of the international community or as Rublee phrases it "dissatisfied with the international status quo". ${ }^{39}$ Because of this the transmission of normative non-proliferation messages are ineffectual because they are coming from an international community they reject or find hard to identify with. This is too simplistic as an explanation and comes from an A-historical perspective which does not explain change. Seven years ago Libya could have been considered an example of this. However today it is the opposite. Israel is outside of the NPT and rejects non-proliferation norms (for its self) but is still an active member of the international community in other areas. The correlation between a sense or feeling of being outside of the status quo and proliferation may be related but are not directly causal. ${ }^{40}$

Rublee's framework is based on three interrelated non-proliferation outcomes that are the result of how individual state's decisions have been influenced and shaped by international non-proliferation norms which have evolved from the regime. Rublee's proposition is that it is the interplay of these three as well as the realist and neo-liberal institutionalist's justifications that collectively best explain state nonproliferation. According to Rublee the rationale behind a state's acquiescence to the norm is just as important, if not more so than its actual acceptance. Understanding why states support the norm sheds light on the circumstances under which this support could be removed. It acknowledges the complexities of the situation both

\footnotetext{
${ }^{39}$ Rublee, Nonproliferation Norms: Why States Choose Nuclear Restraint. Pg 51.

${ }^{40}$ Ibid. Pg 50-51.
} 
domestically and internationally but most importantly allows for and identifies the mechanisms for change. It is not a case of one or other it can be a combination of the three to varying degrees that result in the support of the norm. States could support the norm initially in order to conform but over time internalise the norm resulting in an acceptance through persuasion, so there has been transferral between the outcomes.

Rublee proposes that her constructivist framework can be applied to other nuclear related questions as well as broader IR problematiques. The aim of my thesis is to see if her theory can assist in the explanation of state proliferation.

Rublee emphasises that both realist and neoliberal institutionalism viewpoints are useful for partially explaining state non-proliferation. However, she proposes that her framework, although not perfect, adds a further layer to an explanation of why this has occurred. I will examine the different explanations for two states that are either in the process of proliferating (Iran) or have already proliferated (Israel). Before seeing if social constructivism is a useful tool in explaining non-conformity to regimes and norms. Both case studies offer different challenges to the nonproliferation regime and its norms. They are also interconnected as each state uses the nuclear programmes of the other to justify its own nuclear programme in part. 


\section{Iran: The International Community's Mixed Messages}

\section{The long road to Bushehr}

This section will outline Iran's nuclear programmes and discuss the various, often contradictory, ways in which it has been dealt with by the international community. I will see which paradigms help to identify where the non-proliferation regime has had difficulty in influencing Iran's decision makers and the result this has had.

Iran is the most populated country in the Middle East (over 70 million) and the second largest in size after Saudi Arabia. Geographically it is surrounded by seven countries as well as the Persian Gulf, Gulf of Oman and the Caspian Sea. The Strait of Hormuz, where the Persian Gulf and Gulf of Oman meet is partially within its territorial waters. The Hormuz Strait is a strategically critical body of water that is the key access way for shipping especially for the movement of the world's oil supplies. The US Energy Information Administration (US EIA) calls it "the most critical oil choke point on earth" and has calculated that roughly $35 \%$ of all seaborne traded oil or $20 \%$ of oil traded worldwide passes through this Strait. ${ }^{41}$ Access through the strait, which requires passage through both Iranian and Omani territorial waters, has been negotiated via the UN Convention on the law of the Sea.

Oil and Gas reserves are notoriously difficult to accurately calculate and it is often advantageous to miscalculate them for various reasons. ${ }^{42}$ This acknowledged, Iran is continually and consistently assessed as holding the world's third largest oil reserves and the world's second largest gas reserves. ${ }^{43}$ Iran produces over $90 \%$ of its domestic power capacity from oil, gas and coal fuelled power stations. ${ }^{44}$ The government subsidises domestic oil and gas prices for its citizens because the

\footnotetext{
${ }^{41}$ US Department of Energy, "World Oil Transit Chokepoints," (Energy Information Administration 2010). .

${ }^{42}$ This could be done to misrepresent future state or company earnings or over all stability and this can be both higher and lower. The calculation of this is part of Iran's justification for the acquisition of nuclear power.

${ }^{43}$ US Department of Energy, "Country Analysis Brief: Iran," (Energy Information Administration 2010). ${ }^{44}$ Ibid.
} 
economy could not afford to function if it operated at, or even near, the international market prices. ${ }^{45}$ This huge reliance on oil and gas for domestic power generation and the subsidies on domestic use make sense because of Iran's large reserves. However this domestic use is at the expense of potential export earnings in crucial foreign currency. Iran's population is growing rapidly. Therefore unless change is made increasing domestic consumption will result in decreased quantities of oil and gas for export. Iran's use and distribution of its natural resources is a domestic policy issue and these decisions are ultimately for the Iranians to decide for themselves. However the decision has become important because the domestic decision making process has led to the desire for Iran to develop a nuclear power programme. Iran is one of the original signatories of the NPT which clearly states that it is a right of every sovereign state to pursue such an option. This decision and its ramifications although very topical today is not new. Iran has been pursuing nuclear power technology with varying levels of success since the 1950s.

The Iranians are Persians not Arabs and draw their cultural history from over 3000 years of continuous civilisation. Iranians are almost exclusively followers of Shiite Islam and make up almost $40 \%$ of the total world's followers. ${ }^{46}$ Shiites are approximately $15 \%$ of the world's 1.5 billion followers of Islam making them a clear minority to the Sunni majority. Iranians see part of their national identity as relating back to their being descendants of the once great Persian Empire. This self perception runs contrary to how they are often portrayed by others, which is as an illegitimate, isolationist country with suspect motives.

No exploration of Iran's nuclear ambitions would be complete if it was not cross referenced to the most powerful event in Iran's recent history, the 1979 Islamic Revolution. Prior to the revolution Iran was controlled by Shah Mohammad Reza Pahlavi who had become an autocratic ruler as a result of a CIA backed coup in 1953. The CIA's involvement is not disputed and this has been used as a rallying point for continued anti US sentiment ever since. The Coup saw the overthrow of

\footnotetext{
${ }^{45}$ S Chubin, Iran's Nuclear Ambitions (Carnegie Endowment for International Peace, 2006). Pg 26.

${ }^{46}$ C.M. Blanchard, "Islam: Sunnis and Shiites" (2006). Pg1.
} 
the democratically elected Prime Minister Dr. Mohammed Mossadegh who was subsequently, arrested, imprisoned and then died while under house arrest. The Shah was aligned to the west and implemented wide spread secular reforms. His reforms were known as the White Revolution and focused on breaking the existing power structures in Iran. Land reforms partially undertaken to diminish the strong localised authority of religious leaders were combined with a large investment in both health and education. The result of the reforms was a change to the internal power structures. Power moved from the land owners to the peasants and middle classes. However, the manner in which the changes were carried out created much resentment. This allowed religious leaders to gain support as they became the central and very vocal leaders of popular dissent. Ayatollah Ruhollah Khomeini was one such religious leader. His popularity grew as a result of his increased and very vocal opposition to the Shah's rule. This culminated in his arrest and subsequent exile from Iran. Both Khomeini and Mossadegh were in agreement that the Shah should reign over but not have direct rule of Iran.

Under the Shah Iran began the process of acquiring a nuclear research reactor. A deal was negotiated with the US which saw the sale and construction of a nuclear research facility which became operational in 1967. In 1975 Iran's nuclear foot print was expanded when construction began on the Bushehr nuclear power reactor. The contract had gone to two German companies and it was expected to be finished by 1981.

The US had been a crucial part of the deal and although the construction of the reactor had gone to German companies, the US government was in full support of the deal. National Security Memorandum 292 dated 22 April 1975 and signed by Henry Kissinger in his capacity as the National Security Advisor (he was also the Secretary of State at the time) outlines US Iranian nuclear cooperation. ${ }^{47}$ It details the US's willingness to either; reprocess fusion material for Iran in the US or assist with the building of a multinational reprocessing centre in Iran. This is an important

\footnotetext{
${ }^{47}$ Henry Kissinger, "National Security Memorandum 292 Us - Iran Nuclear Cooperation ", ed. National Security Council (Washington DC1975).
} 
piece of information because it is this full cycle reprocessing capability that has been the major sticking point in all of negotiations with Iran over its nuclear power generation today. Iran has consistently stated that it is its right under article IV of the NPT to have full cycle reprocessing. This capability would effectively mean that Iran would have a self sufficient nuclear power capability. The spent fuel from the reactor could be reprocessed and mixed with ore to produce more fuel for the reactor. Kissinger has since described his support as being based solely on economic considerations and that the idea that Iran would pursue nuclear weapons was not even then considered by the US. ${ }^{48}$ At that time Dick Cheney was President Ford's Chief of Staff and Donald Rumsfeld was his Secretary of Defence. Both of these men were part of the decision making and both of them had supported Iran's nuclear programme. When part of the recent Bush administration it was clear they had both very vocally reversed their opinions on a nuclear Iran.

All US nuclear assistance ceased because of the Islamic Revolution. The Shah was forced into exile and Khomeini returned from his exile and proclaimed himself, with mass popular support, the Supreme Leader of the Islamic Republic of Iran. All work stopped on the Bushehr reactor leaving it less than two years from completion. The Shah had started Iran's nuclear power programme for economic reasons. The more domestic power that could be produced without using their fossil fuel resources the more would be available for Iran to export and earn foreign currency. If the revolution had occurred two years later the Bushehr reactor would have been operational. Instead it is still in its finishing stages today.

The Iranian revolution was a surprise to the world especially the US who believed the Shah had effectively suppressed any internal opposition. This surprise turned to outrage when Iranian students took over the US embassy in Tehran. 52 of the embassy staff were held hostage for 444 days, a situation which has marred USIranian relations ever since. This symbolic action was seen by many Iranians as reclaiming their national autonomy which had been compromised as a result of the

${ }^{48}$ J Cirincione, "Stop the Fuel Cycle, I Want to Get Off," Fletcher F. World Aff. 30 (2006).Pg 28. 
US backed coup in 1953. Saddam Hussein took advantage of both the domestic upheaval that resulted from the revolution and the growing international antiIranian sentiment and invaded Iran. He was attempting to acquire disputed border territories rich in oil and of strategic military importance. ${ }^{49}$ Iraq, like Iran has a Shiite majority however Iraq was controlled by Saddam's Sunni minority which was concerned that the Islamic Revolution could spread to Iraq.

The Iran-Iraq War (known as the First Gulf War) lasted for eight years from 1980 until 1988. Throughout the war most countries supported Saddam Hussein's Iraq. Iraq was supplied, often through very large loans or oil contracts, with weapons, intelligence and technology. The total death toll for the Iranians was close to half a million people. The war ended after peace negotiations and the end result was almost no change to the pre-war borders. Both countries were left with huge debt, huge numbers of causalities and destroyed infrastructure. For Iran the war had the effect of bringing the country together in the common goal of defeating Iraq. This was strengthened as Khomeini not only lacked support from the outside world but also received no affective international condemnation for Iraq's use of chemical weapons against Iranian troops. He used these two factors to unify the Iranian people and emphasise what he saw as the hypocrisy that existed as a result of US hegemony. This continues to resonate today throughout Iran with the US persistently being referred to as 'The Great Satan'. The political system of Iran has effectively aligned in the minds of many of its population the Shah and his regime with the US, his primary supporter, in order to maintain negative US sentiment.

After the revolution Khomeini initially showed no interest in finishing the Bushehr reactor project which he saw as being one of the Shah's US inspired projects. In 1985 during the war he changed his mind because of the potential to use the technology to develop nuclear weapons which could be used to end the war. US pressure against assistance and the poor security situation in Iran resulted in Iran being unable to find anyone to help finish the Bushehr reactor. Iraq also had a

\footnotetext{
${ }^{49}$ This was similar to his motives for the invasion of Kuwait in 1991.
} 
partially constructed reactor in Osirak and in 1980 at the beginning of the war Iran superficially damaged this reactor in an air strike. Israeli, concerned at the prospects of a nuclear enabled Iraq successfully destroy it in $1981 .{ }^{50}$ The Iraqis subsequently bombed the Iranian Bushehr reactor in retaliation. It was after this and during a long stalemate in the war that Khomeini attempted to rebuild the reactor at Bushehr. The rationale for this decision was very different from when the Shah initially started the project. Iran was now at war and the potential utility of the nuclear reactor became its ability to facilitate the production of nuclear weapons. The deterrent effect that would have come from possession of nuclear weapons would have almost certainly guaranteed Iran's victory over Iraq. The US pressure on other states not to assist the Iranians with their nuclear power ambitions came from their legitimate concern that Iran would do just this. It was from this point forward that Iran had to acquire nuclear equipment on a covert basis to avoid international sanctions.

\section{Full cycle nuclear reprocessing and the NPT}

\section{"ARTICLE IV of the NPT}

1. Nothing in this Treaty shall be interpreted as affecting the inalienable right of all the Parties to the Treaty to develop research, production and use of nuclear energy for peaceful purposes without discrimination and in conformity with Articles I and II of this Treaty.

2. All the Parties to the Treaty undertake to facilitate, and have the right to participate in, the fullest possible exchange of equipment, materials and scientific and technological information for the peaceful uses of nuclear energy. Parties to the Treaty in a position to do so shall also cooperate in contributing alone or together with other States or international organizations to the further development of the applications of nuclear energy for peaceful purposes, especially in the territories of non-nuclear-weapon States Party to the Treaty, with due consideration for the needs of the developing areas of the world. ${ }^{51 \text { " }}$

\footnotetext{
${ }^{50}$ For a detailed account of the Israeli military action see, W Raas and A Long, "Osirak Redux? Assessing Israeli Capabilities to Destroy Iranian Nuclear Facilities," International Security 31, no. 4 (2007). Pg 10-11.

${ }^{51}$ Treaty on the Non-Proliferation of Nuclear Weapons.
} 
There are two conflicting interpretations of the above treaty article. Neither dispute the right of Iran to have nuclear power per se just whether it should be allowed the capability for full cycle reprocessing. Iran has been consistent in outwardly stating that it does not want nuclear weapons only nuclear power. ${ }^{52}$ The validity of this statement has been questioned by various states. The result of this has been that Iran's attempts to acquire a nuclear capability have been dealt with inconsistently by the international community.

Article IV is in no way specific on the right for full cycle reprocessing hence the opposing views leave a lot of room for argument. The major and most vocal opponents to Iran obtaining a full cycle reprocessing capability are the US and the EU. The EU's negotiations are led by Great Britain, France and Germany with the focus being on dialogue and diplomacy. They are referred to as the EU-3. They operate as a consensus of three while still having the EU's overall backing. This differs from the US's approach, especially during the Bush administration, which is dominated by a carrot and stick approach. These different approaches stem from the alternative ways in which the two have reflected on the handling of Iraq. The EU-3 emphasized the need to keep the discussions open and to at least listen to Iran's demands with respect. The Obama administration has worked more closely with the EU-3 and its approach. However, considerable differences in the approaches remain.

China and Russia are two key state actors involved in the sale of nuclear power technology to Iran. They are both more pragmatic and focus on their economic relationship with Iran. This relationship gives them all access to foreign currency and petroleum supply security. Both are permanent members of the UNSC which means that their votes would be essential if the imposition of sanctions on Iran was ever put to a vote.

${ }^{52}$ Lavoy, Nuclear Weapons Proliferation in the Next Decade. Pg 151 
The different interpretations of the situation have led to different potential solutions. This has in turn resulted in Iran itself having to have a group of practical responses to meet the varied approaches that others are taking. ${ }^{53}$ The result often appears to be contradictory from outside as Iran juggles the different demands that are placed on it by others.

The main EU-3 position is that if Iran's intentions are only the development of nuclear power then why would it need a reprocessing capability, as it is a much more expensive option. Iran's reply is due to our past experiences we cannot trust other states to guarantee supply of our nuclear fuel requirements. Holland, Germany, France all have the full cycle reprocessing capability, why are we being treated differently? This is an example of western hypocrisy. ${ }^{54}$

The US position is more confrontational; due to past experience and Iran's lack of disclosure of its capability it is better to be safe and deny access to the full cycle reprocessing option or at least retain control over it for Iran. Iran has not disclosed all of its nuclear facilities and some of them are being built underground to make detection difficult and to withstand aerial bombing. The US perspective is that if Iran's intent was for the development of only nuclear power why did they do this as it is guaranteed under the NPT?

Iran's response has been that when we have the full cycle reprocessing capability it will be under IAEA inspection as the NPT stipulates which will ensure that it operates in a transparent manner.

Because the US has denied Iran (including the placing of pressure on other states) that which it was legally entitled to under the NPT we had no choice but to pursue covert procurement from sources like the A.Q. Khan network in Pakistan. In the

\footnotetext{
${ }^{53}$ S. Lodgaard, "Iran's uncertain nuclear Ambitions". Pg 109 in Morten Bremer Maerli and Sverre Lodgaard, Nuclear Proliferation and International Security, Routledge Global Security Studies 1 (Routledge, 2007).

${ }^{54}$ Chubin, Iran's Nuclear Ambitions. Pg 24-25 details the flawed economic logic of this decision and uses Sweden as an example of a country that buys its fuel on the open market which is a much cheaper option. MA El-Khawas, "Iran's Nuclear Controversy: Prospects for a Diplomatic Solution," Mediterranean Quarterly 16, no. 4 (2005). Pg 24 talks about other countries with full cycle reprocessing.
} 
design of our nuclear facilities separation is prudent planning and done by all nuclear powers to spread risk. Israel, a non NPT signatory state, conducted an aerial campaign against Iraq in 1981 we are wary that they may attempt similar military action against us.

The more aggressive US position has been that Iran has lots of oil and gas for the generation of power why does it need nuclear power. ${ }^{55}$ The overall US position is that it cannot trust Iran not to develop nuclear weapons and if it has a full cycle reprocessing capability it would make it easier for Iran to do so. The Iranian reply is that Iran, Tehran especially, is hugely polluted and it needs cleaner power generation. Also the oil and gas we use for power generation is depriving us of foreign currency we need for domestic investment. The Iranian response to the US's inability to trust their real motives is usually redirected towards accusations of hypocrisy and imperialism. The NPT is not clear on this area which gives all actors a lot of space in which to argue the issue.

Iran's regional situation

Iran is philosophically opposed to the Taliban's interpretation of Islam. In Afghanistan's civil war Iran supported the Northern Alliance both financially and materially against the Taliban. Iran's neighbouring enemies, Iraq and the Taliban of Afghanistan, have both been 'defeated' militarily by Iran's strategic enemy the US. ${ }^{56}$ This placed Iran's rulers in a very difficult position. Traditionally the enemy of your enemy is your friend. In this case this is clearly not the case.

Iran's elites have been transparent in their desire to play a wider leadership role within the Middle East, which makes many of these state's elites nervous. Many of the other states in the region are secular and see the Islamic republic as a threat.

\footnotetext{
${ }^{55}$ Henry Kissinger's quote appears in El-Khawas, "Iran's Nuclear Controversy: Prospects for a Diplomatic Solution."Pg 21. This is the opposite of what he said in 1975. His 1975 position is now the same as the Iranian position. We were allies then now we are not, was his response about the perceived contradiction.

${ }^{56}$ G Bahgat, "Nuclear Proliferation: The Islamic Republic of Iran," International Studies Perspectives 7, no. 2 (2006). Pg 313. The continued counter insurgency in both states has made the eventual outcome difficult to predict.
} 
Egypt and Saudi Arabia see themselves as potentially filling this wider leadership role so are also concerned. The impact of Iranian regional dominance is seen by Israel as being potentially disastrous. President Ahmadinejad's rhetoric aside, Iran does not formally acknowledge the existence of Israel and actively funds Hamas and Hezbollah to resist any extension of Israeli territory as well as undermining its claim to legitimacy. Israel's close ties with the US and Iran's hostility towards both states has resulted in Iran seeing both states as the same threat just from different geographical locations. In essence Israel and the US are a supranational threat to Iran. $^{57}$

During the 1990s, Iran's relationship with most of the outside world improved. The Second and Third Gulf Wars represented a different US and international reaction to Iraq. This concurrently improved Iran's security situation, by defeating Iraq on the battle field, and lessened it, because of the concentration of US led forces on its border. The lack of assistance during The Gulf War had shown that Iran did not have any neighbouring allies. Within the wider region those that did assist did so through covert means with the sale of weapons usually for oil. It is clear, and Iran's foreign policy has always reflected this, that no effective security guarantee from other states exists.

It does have relationships with some states, however, these relationships tend to be based on economic utility, especially the supply of oil and gas. In return Iran has been able to import limited consumer goods, military hardware and technology primarily from Russia (USSR), China, India, Pakistan and especially DPRK. This has sometimes been overtly stopped under pressure from the US and some European states and other times this has occurred more indirectly.

The US's recent bilateral agreement with India (one of the three non signatory states of the NPT) facilitates the sharing of nuclear power technology. This has been driven by the US's desire to lower India's dependency on Iranian oil and gas

\footnotetext{
${ }^{57}$ A Kadhim, "The future of nuclear weapons in the Middle East", Pg, 153 in Lavoy, Nuclear Weapons Proliferation in the Next Decade.
} 
imports. ${ }^{58}$ The US's bilateral actions, like this deal with India, have diminished the power of the non-proliferation regime in the eyes of the Iranians. Iran perceives the application of US double standards as occurring without any effective condemnation from the international community. India, as a non signatory of the NPT, should not be eligible for nuclear technology from a NPT signatory, in this case the US. The US is seen as effectively placing a higher importance on strategic goals than it has on upholding its NPT obligations. India has refused to sign the NPT for ideological reasons which stem from the selective cut off date for the acquisition of nuclear weapons (once the dominant powers had got them), and an attempt to restrict technology transfer to developing countries.

The Group of Nuclear Suppliers (GNS) was established to limit the sale of nuclear technology to non NPT countries and to ensure that the IAEA was aware of any such sales. This is to enable the IAEA to verify that what states say and do is the same thing. In a contradictory response the GNS opposed the US arrangement with India while the Director General of the IAEA supported it. He did so because he saw it as a way of verifying some of the capability of a non signatory state and as a step forward to bringing India in line with the non-proliferation regime. Again Iran sees this as hypocrisy in action.

Iran has a comprehensive educational system and as a consequence of its international isolation has had to be self sufficient in a diverse range of areas. This includes scientific personnel with training in nuclear technology. Much of this training has come from overseas, some from Russia, China and there is evidence that Iranian scientists were present at the DPRK's long range missile launch in 2006. ${ }^{59}$ The complexity of nuclear missile technology means that firsthand experience of its operation would be essential if it were to be replicated by a country with Iran's level of resources. Nuclear technology costs a lot of money and no country would give it away for free. Iran's energy resources are an ideal

\footnotetext{
${ }^{58}$ Delpech, Iran and the Bomb: The Abdication of International Responsibility. Pg 59-60.

59 Ibid. Pg 73-74.
} 
bargaining chip and even Pakistan through the A.Q. Khan network has been willing to risk US disapproval to gain access to this resource. ${ }^{60}$

\section{The proliferation decision making of the elites}

Iran has a unique power structure in which supreme control is held by a nonpopularly elected Ayatollah. The head Ayatollah (known as the Supreme leader) is selected by a small council of guardians who also have final say over all candidates for the wider "democratic" elections. After Khomeini's death in 1989 Ayatollah Khamenei replaced him and he is still in power today. It is the Supreme Leader and the council of guardians that hold the real power and the elected president and parliament operate within a limited sphere. All foreign policy decisions have to be approved at the highest level. The council controls the Revolutionary Guards (as the name suggests they are the guardians of the ideals of the revolution) who in turn controls all nuclear capability. The reality is that despite President Ahmadinejad's rhetoric, although influential, he does not have control over Iran's nuclear programmes.

Almost no public debate occurs around nuclear proliferation in Iran which is the same as in Israel. Any potential UNSC economic sanctions against Iran because of its nuclear programme would have a negative effect on the lives of average Iranians. The issue for Iran is the balance between being nuclear self reliant and the prestige that this is perceived to bring, and the economic consequences of doing so outside of the non-proliferation regime. Iranians have been closely watching the DPRK's decision to proliferate and the continued suffering of the citizens that has been a consequence of this. To disregard the international regime can possibly bring an increased feeling of autonomy and international respect (or fear) but this would come at a huge economic and social cost. Although much public debate is removed from the actual decision making process events like President Bush's 2003 speech in which he named Iran as part of the 'Axis of evil' has had the effect of bringing

\footnotetext{
${ }^{60}$ For account of Iranian dealings with Khan network see especially centrifuge technology, D Albright, "When Could Iran Get the Bomb?," Bulletin of the Atomic Scientists 62, no. 4 (2006).
} 
popular support behind Iran nuclear power programme and reemphasised the need for self reliance. ${ }^{61}$ The invasion of Iraq has affected how Iran perceives security and is partially responsible for the election of the ultra conservative President Ahmadinejad. His support has decreased over time and the 2009 Presidential election, of which the results were disputed, resulted in massive populist protest marches.

Iran is still a member of the NPT. It has not seriously threatened to leave the NPT as DPRK did in the early 1990's, eventually leaving in 2003. The regime is seen as having clear utility for them as a country especially given its troubled relationships with its neighbours and other regional states. A highly nuclearised Middle East would be as negative for it as it is in the minds of much of the world's elites. Iran has been and continues to be very vocal over what it perceives as the double standards that exist in the treatment of different states. Using Rublee's terminology for the transmission of the non-proliferation norms, Iran focuses on the descriptive norms of other states, that is, state's actions not their rhetoric. ${ }^{62}$ Iran uses this interpretation rather than proscriptive or injunctive norms to shape its interpretation of subjective norms. By emphasising the actions of other actors it is able to move the spotlight away from itself.

The constant presence of perceived conflict through potential external threats limits the potency of the non-proliferation norm. The existence of this conflict and the many different approaches that states and institutions have used with Iran has allowed it to play one of them off against the other to Iran's advantage. The consequence of this has been a muddying of the waters and the inability of the parts of the regime to work together to ensure that Iran complies with its international obligations under the NPT. The often contradictory approaches from members of the international community have greatly affected how the Iranian

\footnotetext{
${ }^{61}$ Chubin, Iran's Nuclear Ambitions. Pg. 28, refers to polls of up to $80 \%$ domestic support for Iran's nuclear power programme.

${ }^{62}$ Rublee, "Taking Stock of the Nuclear Nonproliferation Regime: Using Social Psychology to Understand Regime Effectiveness."Pg 426
} 
decision makers have processed non-proliferation norms in favour of what they want rather than what they are entitled to under the regime. ${ }^{63}$

Iran has been to war with its neighbour Iraq and this neighbour has in turn been invaded by Iran's long term adversary the US. This has led to a fear that the same could also happen to Iran. Being labelled as part of the "axis of evil" had the effect of compounding this. Although no immediate threat exists, Iran's position is such that it cannot rule out one emerging from its neighbours or as the Gulf Wars have shown from the US and its allies. Based on past experience Iran has no state or collection of states from which it can realistically expect effective overt support. This is especially true if the threat came from the US. The US has operational combat troops in two of Iran's neighbouring states (Iraq and Afghanistan) as well as an extensive presence in Turkey. The US also has access to airfields and ports in Pakistan, Azerbaijan, Turkmenistan as well as numerous military installations across the Persian Gulf. Iran is effectively surrounded and although military action against it has not occurred, the possibility of it happening in the future is likely to shape the elites decision making. US actions such as the Bush administration's 2004 sale to Israel of 500 bunker-busting smart bombs, which are capable of penetrating thick concrete like that found in nuclear installations, only adds to its insecurity. ${ }^{64}$

Because Iran already sees itself as a target, some commentators believe that the acquisition of nuclear weapons would not increase but effectively decrease the current threat situation. ${ }^{65}$ Iran has closely watched the DPRK leaving the NPT and then conducting nuclear tests. This case has exposed the limitation of any effective intervention against its proliferation and emphasised the toothlessness of the nonproliferation regime in this instance. ${ }^{66}$ Iraq and Afghanistan have collectively

\footnotetext{
${ }^{63}$ S.N. Kile, "Europe and Iran: Perspectives on Non-Proliferation," (A SIPRI Publication, 2005). Seyed Kazem Sajjadpour, Ch 2 Pg 25-26.

${ }^{64}$ http://www.jewishvirtuallibrary.org/jsource/US-Israel/bombsale.html

${ }^{65}$ M Kibaroglu, "Good for the Shah, Banned for the Mullahs: The West and Iran's Quest for Nuclear Power," Middle East Journal 60, no. 2 (2006). Pgs 219-222.

${ }^{66}$ Delpech, Iran and the Bomb: The Abdication of International Responsibility. Pg 73, Delpech goes as far as to speculate that Iran and DPRK coordinate their actions of dissent to take advantage of the West's inability to deal with two "crises" at once. The same idea is in M Fitzpatrick, "Iran and North Korea: The Proliferation Nexus," Survival 48, no. 1 (2006). Pg 66, Fitzpatrick also reverses it that if the
} 
exhausted the appetite of many developed countries for large scale military intervention. The diplomatic approach, which has been more favoured by the Europeans, has become more popular, if not more effective. The non-proliferation regime has lost some of its perceived influence through its inconsistent application. The US's bilateral arrangement with India, the continued silence on Israel's nuclear capability and the willingness to forgive Pakistan's nuclear proliferation in favour of its material support for the war in Afghanistan have all added to this. ${ }^{67}$ Iran sees itself as a potential target with or without nuclear weapons. This has been used by some of its elites to justify their covert development.

Iran continually proclaims that it is only interested in a nuclear power capability while continuing to do everything possible to make it impossible to confirm the validly of this, as well as behaving in such a manner as to raise legitimate doubts about this intent. Realists have argued that if a state wants nuclear weapons the rational self help thing to do is to use NPT membership to develop nuclear power. Then it should leave the NPT and develop nuclear weapons utilising the technical knowhow it has gained. This is similar to what the DPRK has done. Concern that Iran will do the same underlies most of the objections to it having a full cycle reprocessing capability.

non-proliferation regime can convince one state to stop the other will be under more pressure to also stop.

${ }^{67}$ G Bahgat, "Nuclear Proliferation in the Middle East: Iran and Israel," Contemporary Security Policy 26, no. 1 (2005). Pg 29, describes the Iranian belief in their cultural superiority over the Pakistanis. It is because of this that they have taken offense to the lenient treatment that Pakistan has received over their nuclear programmes. 


\section{Israel: Special Friendships to Maintain a Nuclear Monopoly}

\section{The short road to Dimona}

Israel my second case study, like Iran it provides a complex challenge for attempting to explain why states chose and continue to choose nuclear proliferation in opposition to the dominant non-proliferation norms. Starting with an overview of Israel's security environment, its domestic nuclear policies and then an account of how it has acquired nuclear weapons. Finally, concluding with an analysis of why I think Israel has an undeclared nuclear weapon capability in opposition to a powerful non-proliferation norm.

I have chosen Israel as one of my case studies because it is not a signatory of the NPT and therefore is to an extent outside the direct impact of the international nonproliferation regime. Because of this Israel's case poses an interesting challenge of how a norm affects those that are not legally bound by it. Israel has had nuclear weapons since the late 1960 s and has continued to further develop this capability since then. During this time the international non-proliferation regime has developed into an influential tool to shape state behaviour. Partially because of Israel's special relationship with the US Israel's behaviour has not been condemned by any state or group of states in any effective way. Israel's complex security situation has resulted in it defining security almost exclusively in militarily terms. The manner in which the modern state of Israel was created and the rationale and historical context behind this establishment are other key parts. It is the interplay of these elements that I will examine in attempt to explain not just why it started a nuclear programme but more importantly why Israel maintains one in the highly secretive manner in which it does outside of the international regime.

Israel is small country on the eastern end of the Mediterranean sea. Within its current borders exist some of the longest continually inhabited areas of the world. The birth of the state of Israel was a difficult and very controversial process. The Zionist movement, which was established in Europe in the $19^{\text {th }}$ century, was the 
international political movement behind the lobbying of sympathetic governments and institutions for a return to the Jewish homeland. The movement drew on religious sources like the Torah, for its references to the right of the Jewish people to return to their ancestral homeland. The movement saw this as giving them the right to claim territory that was occupied by Palestinians. The growth of support for the movement occurred within a larger context of growing European anti-Semitism which culminated in the holocaust.

The Jewish right of return is still an important point today which shapes the Israeli perspective. Israeli's are not occupiers, vanquishers or imposters but rather the rightful inhabitants returning to their rightful territory as promised to them by God. Regardless of how many believe this to be literally true it has been woven into the identity of Israel effectively enough to no longer be able to be debated or separated from it. The sense of rightful entitlement to return was reinforced by the horrors of Nazi Germany's actions against the Jewish people. These gave rise to a powerful determination to support the establishment of a Jewish state.

Palestine was under British mandate after World War I and it was during that time that a stream of Jewish settlers moved to Palestine and bought land. In 1948, legitimised by a UN mandate, David Ben-Gurion declared the creation of the state of Israel and became its first Prime Minister. ${ }^{68}$ This had followed a period of conflict between the Jewish settlers and both the British and the Palestinians. The establishment of the Jewish state has remained controversial since its inception. The original state of Israel was a sub part of Palestine and the intent was for the two states to exist side by side.

The Arab states that surround it have all collectively and individually been involved in conflict with Israel. Israel has won every one of those conflicts and at different times has occupied parts of those state's territories. A strong conventionally armed military with near universal conscription has existed in Israel from its inception. Because Israel is so small geographically it has adopted the doctrine of pre-emptive

${ }^{68}$ A Cohen, Israel and the Bomb (Columbia Univ Pr, 1998).Pg 9. 
strikes taking the battle out of its borders as quickly as possible. After Israel developed nuclear weapons they were incorporated into its doctrine as an option of 'last resort'. This is because the countries it has been to war with, Lebanon, Palestine, Jordan, Egypt and Syria, are all on its borders. So the deployment of a nuclear weapon would potentially be self destructive. The four conditions required for the deployment of nuclear weapons are; firstly a successful Arab penetration into populated areas within Israel's post 1949 (since been changed to post 1967) borders, secondly the destruction of the Israeli air force, thirdly the exposure of Israeli cities to massive and devastating air attacks or to possible chemical or biological attacks, and lastly the use of nuclear weapons against Israeli territory. ${ }^{69}$

Israel has never used its nuclear weapons because its defence force has decisively won every military engagement it has been involved in. After every war elements of the international community have been part of the subsequent peace negotiations. What has evolved from this is what many refer to as a "cold peace" in the region. Many of the grievances that led to the wars still exist but the overwhelming military strength of Israel, which has been proven on the battlefield, has made the diplomatic option the only feasible course of action for its neighbours.

Israel maintains one of the worlds' most highly trained and equipped defence forces through conscription and foreign armament purchases. It is essentially always on the alert and permanently militarised to meet any future threat. In Israel the extent of this military commitment can be seen in the very large proportion of its GDP that is spent on the military. Over the last decade this has averaged $8 \%$ (this does not include military aid from the US). ${ }^{70}$ It peaked at $25 \%$ in the early eighties.

The Palestinians have had very little say in their situation and are constantly used as pawns in Israel's discussions on security. Rockets and suicide bombers that originate from Palestine are used as justification for offensive military campaigns into the

\footnotetext{
69 Ibid. Pg 237.

70 P. Stalenheim, C. Perdomo, and E. Skons, "Military Spending and Armaments," SIPRI Annual report (2006).Pg 203-4.
} 
Palestinian territories in the name of security. The Israeli situation leads to emotive polarisation of viewpoints and reflects highly subjective and often normative assessments. What is clear is that Israel has faced existential threats throughout its history and every time a threat has occurred it has met the threat with conventional forces and won. ${ }^{71}$ The deterrent effect of their undeclared nuclear capability is impossible to precisely determine, but it is reasonable to assume that it has been and remains a factor in the decision making process of the elites of past and potential adversaries. It is this monopoly on the nuclear deterrent within the Middle East that Israel is so focused on maintaining.

\section{Foreign support and special relationships}

In looking at Israel and its nuclear programme my focus is on two areas. Firstly, the actions of the Israeli elites and how they enforced almost total secrecy around the nuclear programme ensuring that it has never been publicly debated. Secondly the inconsistent manner in which the international community, the US especially, has reacted to and continues to react to Israel's nuclear programme. To better understand these two factors it is important to also explain the powerful linkages to both the Jewish holocaust of World War II and the manner in which the Jewish state was established as an ethnic democracy. ${ }^{72}$

Israel's first Prime Minister, David Ben-Gurion, travelled to the concentration camps at the conclusion of World War II to witness firsthand the extent of the holocaust. ${ }^{73}$ It was this experience that reinforced his view of firstly, the need for a Jewish homeland in which all Jews would be safe. And, secondly, that the Jewish people

\footnotetext{
${ }^{71}$ The existence of Israel's nuclear weapons has influenced the elites of attacking states in how and with what they have attacked Israel. During the Gulf War Iraq fired scuds missiles at Israel, these missiles are capable of carrying chemical weapon payloads but were only armed with high explosives warheads. Iraqi knowledge of Israeli nuclear doctrine meant that any use of chemical weapons against Israel could result in nuclear retaliation.

${ }^{72}$ Ethnic democracy is a democratic structure shaped to reinforce the dominance of one specific ethnic group within a multi cultural environment. S Smooha, The Model of Ethnic Democracy (European Centre for Minority Issues, 2001).

${ }^{73} \mathrm{M}$ Karpin, The Bomb in the Basement: How Israel Went Nuclear and What That Means for the World (Simon \& Schuster, 2007). Pg 23. Cohen, Israel and the Bomb. Pg 10-11.
} 
could not rely on gentiles to protect them, therefore the Jewish homeland must be defended by Jews. The extreme nature of Nazi treatment of the Jews was the final straw in what had been centuries of varying degrees and forms of persecution that the Jewish minorities faced throughout much of the world. Cohen goes as far as to say that it was the holocaust that provided Israel (through Ben-Gurion) with the "justification and motivation for the (nuclear) project" ${ }^{74}$

The Israeli nuclear reactor at Dimona (in the Negev desert in southern Israel) was built with French technological assistance. The French were assisting in part because of a sense of solidarity in their opposition against the Arabs. The French regularly had to suppress separatist's rebellions in Algeria which they believed were being funded by Nasser in Egypt. The French thought that a strong Israel would distract Nasser and force him to keep his attention on his immediate neighbours. ${ }^{75}$

Israel's nuclear programme started in 1957. As a consequence of pressure from various states Israel had to regularly source separate pieces of equipment from different countries to blur the line between nuclear power research and nuclear weapon development. ${ }^{76}$ The Six Day War of 1967 between Israel, Jordan, Syria and Egypt signified a change in Israel nuclear policy. If Israel did not have operational nuclear weapons prior to the war, it was the trigger for it to assemble one. ${ }^{77}$ Israel has never overtly tested a nuclear weapon which has assisted them maintain what is now referred to as a policy of opacity. ${ }^{78}$ Originally this policy was described as one of ambiguity by the Israeli elites however this was forced to change as a result of the NPT. Israel was finding it more difficult to no longer declare where it stood with

\footnotetext{
${ }^{74}$ Cohen, Israel and the Bomb. Pg 10.

${ }^{75}$ Ibid. Pg 49.

${ }^{76}$ Ibid. Chapters 4 and 5 go through this process in detail.

77 Ibid. Chapter 15. Discusses the Israeli fear of a Egyptian attack on Dimona and the acceptance of the limitations of nuclear weapons. This limitation comes from the close proximity of Israel's enemies to itself which means they can only be used as a last resort.

${ }^{78}$ There is some speculation that a seismic event detected in the Atlantic by a US satellite in 1979 was a combined South African Israeli test but this has never been collaborated.
} 
regards to its nuclear capability. The result was that Israel moved to an official policy of opacity and reached a compromise with the US over its non disclosure status. ${ }^{79}$

As was the case with Iran, Henry Kissinger was the person advising the US president on what to do. This resulted in 1970 with Israel promising the US that it would not be the "first country to introduce nuclear weapons into the Middle East". ${ }^{0}$ The agreed definition of what introduced meant was the testing of or deployment of nuclear weapons. Israel saw the benefit of maintaining this promise because it acted as a form of insurance. It insured that the US would continue to supply Israel with its conventional weapon requirements ensuring a military technological advantage over its adversaries. The Israeli nuclear doctrine outlined in the previous section meant that they were only a weapon of last resort, so if Israel had to break the promise with the US, it would be as a consequence of near or total military defeat. This special relationship with the US remains today and Israel is the recipient of an estimated three billion dollars' worth of what is termed 'military aid' annually. ${ }^{81}$ This 'aid' is a key part of the special military technology transfer relationship that they share, but is limited to the transfer of conventional weapons. Although they are conventional weapons they are highly advanced weapons such as missile and missile defence systems and fixed and rotary attack aircraft, which ensures Israel's military dominance.

The consequence of this policy is that Israel neither confirms nor denies its weapon capability both internationally in the diplomatic arena, and also internally in any form of domestic political debate. The combined consequence of Israel's policy of opacity and the fact it is not a member of the NPT means Israel is the only state that has made itself exempt from any form of scrutiny of its nuclear position both domestically and internationally. This has been allowed to happen largely because

\footnotetext{
${ }^{79}$ The use of the word opacity comes from Cohen, Israel and the Bomb. Cohen describes ambiguity as being able to mean either; a lack of clarity or certainty of capability; or ambivalence of those in charge. Opacity means that Israeli nuclear status has not be acknowledged but is recognised in ways that influence the perceptions and actions of other states when dealing with Israel. These words and their definitions have been adopted by the academic community.

${ }^{80}$ Ibid. Pg 236 \& 338.

81 JM Sharp, "Us Foreign Aid to Israel," ed. Report for Congress (2009).
} 
of US backing. As Israel was being established a small group of elites led by Prime Minister Ben-Gurion decided that Israel would have nuclear weapons to ensure that the holocaust would never happen again. This decision has since been continuously supported by subsequent elites. ${ }^{82}$ When Rublee writes about how states process norms she uses the word consistency. In this context she means past behaviour as being the best predictor of future behaviour. Israel made its decision to pursue the nuclear option before the establishment of an effective non-proliferation norm. This decision had had twenty years to be internalised by the elites. It was internalised, even bureaucratised by those at the very top who had knowledge of the secret nuclear programme. The fact that Israel has not faced any serious repercussions for this policy has led many of the Israeli elites to regard this as proof of its success and plays a role in the strong opposition to changing it.

\section{Opacity and the elites}

Prime Minister Ben-Gurion, the first and longest serving Prime Minister of Israel was the key person in establishing Israel's nuclear weapon programme. Cohen describes how it was the decisions that he made at the crucial period of the establishment of the state of Israel when he, and a small number of his elites, had almost complete control over all key decision making. At the time that was considered necessary because of the huge challenges that the emerging Jewish state faced on many fronts. It had no industrial base which meant very limited economic activity. It had had to fight for the initial establishment and continued possession of its territory so its long term security was far from certain. It had a constant influx of Jewish immigrants returning to the homeland who needed to be employed, and the necessary social infrastructure had to be established to support them. The establishment of the collectivised Kibbutz were part of the initial solution to some of these challenges and were seen as an important building block in the building of the state.

\footnotetext{
${ }^{82}$ Cohen, Israel and the Bomb. Chapter one has the full account of the decision process.
} 
Cohen argues that Prime Minister Ben-Gurion was the only leader who has ever had the capability through his near absolute moral and bureaucratic authority to instigate the secret nuclear development. ${ }^{83}$ The timing was critical because in the mid to late 1950's no effective international non-proliferation norm existed to counter Ben-Gurion's nuclear aspirations.

It was Israel's special relationship with France that allowed this desire to become a reality. France facilitated the transfer of the necessary technology to build the Dimona reactor and fuel reprocessing capability without any effective safe guards against future nuclear weapon production. Without this assistance Cohen speculates that by the time Israel could have developed the same capability internally the domestic political situation would have been vastly different. International norms would have had to be seriously considered and the more open democratic processes would have made the secrecy, surrounding the nuclear programme, much harder if not impossible to replicate. The decision by Prime Minister Ben-Gurion and the assistance by the French had opened the door and firmly established the path to nuclear weapon production. Future governments were compelled to keep this a secret. This was partially reinforced by the establishment of non-proliferation norm because to make it public would not only mean that Israel had to confess to going behind the back of the international community but also expose the complicity of other states that had assisted it. Norway sold it the heavy water it required for its reactor and British bureaucrats, through a Norwegian company and without official government approval, sold it some of the necessary dual purpose technology for its nuclear programme. ${ }^{84}$

Cohen's in-depth research and informed observations in his book "Israel and the $B o m b^{\prime \prime}$ is considered the seminal work on how and why Israel acquired its nuclear capabilities. It is limited in that it is a historical analysis and although it draws from a variety of sources and is highly regarded, it does not effectively address the

\footnotetext{
${ }^{83}$ Ibid. Pg 341

${ }^{84}$ Over view of British and Norwegian assistance to Israel. David Leigh, "How the Uk Gave Israel the Bomb," The Guardian 2005. J J B Hunt, "Pm Office," ed. Joint intelligence Commitee (London: National Archive UK, 1961).outlines UK complicity and nuclear sales. Accessed 4 February 2010
} 
question of why Israel continues to reject the near universal non-proliferation norm. His conclusion is that the current policy of opacity is outdated and no longer supports Israel's best interests. His book finishes at the end of the 1960s with Israel acquiring nuclear weapons.

Rublee's book uses case studies of states that have either acquired nuclear weapons or the capability to develop them and then consciously decided against continuing down that path. Her premise is that it was the way in which the states reacted to or embraced the international non-proliferation norm that resulted in this change of national policy. What makes Israel different? Why has the subsequent strengthening and enforcement of this international norm not changed what is still today a policy of nuclear opacity?

A big part of the answer to this comes from how Israel has been allowed to maintain its policy of opacity when it is not supported by the facts. Mordechai Vanunu, who was a technician at the Dimona nuclear facility, is the most well known example of a person who has exposed Israel's nuclear weapon capability. He did so in 1986 by providing detailed information, including photos taken from within Dimona showing parts of nuclear weapons. He provided this information to a journalist from a British newspaper, the Sunday Times. After the publication of this information he was caught in a Mossad honey trap. He went with the agent to Rome from where he was abducted to Israel. In Israel he was tried and convicted in secret for treason and espionage and sentenced to 18 years imprisonment most of which was served in solitary confinement. ${ }^{85}$ This is an example of the sort of lengths that the Israeli government has gone to, to protect its stance of nuclear opacity. By maintaining the policy of opacity the government has effectively side stepped any application of the non-proliferation norm to itself. Israel's unique security situation, being surrounded by past adversaries, and the perceived benefit from holding a nuclear monopoly in the Middle East by way of its policy of opacity is seen as acceptable to it and the US.

\footnotetext{
${ }^{85}$ Yoel Cohen, The Whistleblower of Dimona: Israel, Vanunu, and the Bomb. (Holmes \& Meier Publishers, 2003). This book outlines Vanunu's story and puts it into the context of Israel's nuclear programme. Also see Bahgat, "Nuclear Proliferation in the Middle East: Iran and Israel." A different perspective.
} 
Israel is the only democracy in the world that has a military censor who operates on a permanent basis. ${ }^{86}$ As a consequence of there being no formal acknowledgement of Israel's nuclear capability there is no open public debate on the issue. Similar debates occur, at least to some degree, in all other states with some nuclear capability, and all of those that are democracies. The most prominent academic who has focused on Israel's nuclear history is US based Avern Cohen. Over the last 20 years he has written many books and articles on the subject however he no longer travels to Israel for fear of interrogation and/or arrest.

Israel is an ethnic democracy. A liberal democracy embraces diversity and multiculturalism to produce a collective identity. An ethic democracy although incorporating some diversity has one dominant ethnic group. In the case of Israel it is the Jewish ethnicity, which is the central basis for domestic and international policy decisions. ${ }^{87}$ Sammy Smooha, an academic who has extensively researched ethnic democracies describes it as follows:

"Israel is a diminished ethnic democracy and not a liberal democracy because the state recognizes ethnic groups, and not just individuals. It is neither a liberal nor a multicultural democracy because it makes the Jews a core ethnic nation and the Arabs non-core outsiders." ${ }^{\prime 8}$

Smooha suggests that the model of ethnic democracy is particularly valid for democratising states that attempt to manage their divided societies without giving up structured majority dominance. ${ }^{89}$ The dominant Jewish Israeli perception is that Israel is a western liberal democracy, and that Israel can be democratic and Jewish at the same time. This view has been accepted by Western liberal democracies even though it is not correct. The initial UN mandate of 1947 allowed for the formation of two states one Jewish and the other Arab. This action has internationally legitimised the merging of democracy and Jewish dominance which has resulted in Israel being

\footnotetext{
${ }^{86}$ A Cohen, "The Bomb That Never Is," Bulletin of the Atomic Scientists 56, no. 3 (2000).Pg 22 and Karpin, The Bomb in the Basement: How Israel Went Nuclear and What That Means for the World.Pg ix-x. Is a detailed explanation of how this operates and how it evolved to be the way it is today. ${ }^{87}$ Smooha, The Model of Ethnic Democracy.

${ }^{88}$ Ibid. Pg 55.

${ }^{89}$ Ibid. Pg 5.
} 
an ethnic democracy. In other words, there is international legitimacy for the existence of an ethnic democracy in Israel. ${ }^{90}$

Israel has never signed the NPT therefore it is not breaking any existing international law or enforceable obligation as a result of its ownership of nuclear weapons. What it is doing is standing outside of a very powerful international regime, one which has near total state membership and by any measure has been a resounding success in limiting nuclear proliferation. ${ }^{91}$ Although Israel is not a signatory to the NPT, and as a result not subject to the independent inspections by the IAEA that signatory states are, it remains an out spoken critic of other states who attempt to acquire nuclear capability.

Israel's criticism has been directed at states that are signatories of the NPT, and thus states that are subject to IAEA inspections as well as UNSC sanctions for treaty violations. These states (at least the elites of the states at the time of signing the NPT) have voluntarily made their states accountable to both international law and the reinforcement of the dominant non-proliferation norms. This means that Israel, itself not bound by established non-proliferation international law (and its associated sanctions), is using the NPT and its associated broader non-proliferation norms as a foreign policy tool to justify criticism of selective states that it perceives as threatening its security. This has occurred while Israel is not legally accountable for its actions under international law and hence removed from the enshrined checks and balances that signatories face.

Iraq and Iran are both examples of countries about which Israel has been very outspoken in relation to their acquisition of any nuclear capability. In the case of Iraq this went beyond just talk, to the unilateral aerial bombing of its nuclear

\footnotetext{
${ }^{90}$ Ibid. Pg 56.

${ }^{91} 189$ out of 193 states makes it near universal and the number of new nuclear weapon states since it its inception has be far less than almost all predictions.
} 
facilities in 1981. Israel continues to make overt threats to carry out the same actions against Iran today. ${ }^{92}$

Israel has not as yet done the same to Iran because the Iranian installations are more geographically dispersed with some close to population centres. Also the bombing of the Iraqi facilities actually encouraged Iraq to seek nuclear weapons it just made them more careful to hide their nuclear programmes in the future. ${ }^{93}$

This raises the question of what impact Israel's stance has on the international nonproliferation norm? Does it strengthen or weaken the norms standing in the eyes of other states? Has the non-proliferation norm failed in the case of Israeli, or is it as much of the literature suggests, a case of "Israeli exceptionalism". That is, that the specific security circumstances and the continuously repeated existential threats made against Israel, placed into the historical context of the holocaust, mean that a separate standard is justified, or at least acceptable to the dominant world powers. If this is the case then it must be a case of the Israeli identity being the dominant factor in its decision to proliferate. This must have overridden the influence of social conformity because the perceived existential threat environment will always result in the security benefits side of proliferation dominating any discussion regardless of the cost. Put simply, survival at any cost is more highly valued than the international consequences of attaining and maintaining what is believed to be a guarantee of that survival. Alternatively the protection of international institutions is acceptable for other states but not necessary for Israel.

\footnotetext{
${ }^{92}$ For discussions on this option see; RK Betts, "The Osirak Fallacy," The National Interest (2006). As well as; Raas and Long, "Osirak Redux? Assessing Israeli Capabilities to Destroy Iranian Nuclear Facilities."

${ }^{93}$ Betts, "The Osirak Fallacy." Pgs 22-25.
} 


\section{Iran and Israel Non-Conformity to Norms}

In her conclusion Rublee states her central argument and the conclusions she has reached as follows;

"This book has argued that the international social environment, supported by first an emergent and then a full-fledged nuclear non-proliferation regime, has helped to provide that systemic impetus towards nuclear non-proliferation." 94

She continues;

"First, not all nuclear forbearance is alike. Some states may be persuaded, others may be constrained by social conformity, and still others may identify with important allies. Second, it is important to identify and understand the mechanisms through which the social environment exerts influence."

In reviewing her book Nina Tannenwald, who has written extensively on the nuclear taboo, asks if Rublee's framework could be tested in a more robust manner if one looks at the international normative environment and its effects on state's behaviour when the outcome is proliferation. ${ }^{96}$

"...since the conceptual framework she (Rublee) lays out in principle ought to be able to explain decisions for proliferation as well as forbearance."

Referring to state nuclear proliferation, Tannenwald asks,

"Did the norms fail, did constructivism fail or did both succeed but in undesirable and unanticipated ways?"98

So far I have detailed three approaches to looking at state nuclear proliferation and then applied them to Iran and Israel. I will now look at the constructivist approach in more detail and also explore some of the external, (from the regime) influences that have shaped these two state's desire to proliferate.

\footnotetext{
${ }^{94}$ Rublee, Nonproliferation Norms: Why States Choose Nuclear Restraint. Pg 202.

${ }^{95}$ Ibid. Pg 221.

${ }^{96}$ See N Tannenwald, The Nuclear Taboo: The United States and the Non-Use of Nuclear Weapons since 1945 (Cambridge Univ Pr, 2007). - - - "Stigmatizing the Bomb: Origins of the Nuclear Taboo," International Security 29, no. 4 (2005). \& - - , "The Nuclear Taboo: The United States and the Normative Basis of Nuclear Non-Use," International Organization 53, no. 03 (2003).

${ }^{97}$ Nina Tannenwald, "Deciding Not to Join the Nuclear Club," The Nonproliferation Review 16, no. 3 (2009).Pg 532.

98 Ibid. Pg 532.
} 
I begin by looking at persuasion, identity and social conformity in relation to my two case studies. It is obvious that neither of my case studies can be put into one of these three groups, as Rublee's can, because they have not effectively accepted the non-proliferation norm. However by working through her concepts of transmission, processing and potency it is possible to see if and why they fit or fail to fit. This process assists in identifying whether there are actual shortcomings in the nonproliferation norm, or the regime, or whether it is something external that allows this to happen.

Israel has clearly not been persuaded that following the non-proliferation norm is in its best interests. It has been reported that the words "never again" (referring to the holocaust) are welded in Hebrew and English on to the first Israeli nuclear weapon. ${ }^{99}$ From Prime Minister Ben-Gurion's initial decision to pursue nuclear weapons there has never been any change in policy. Control of the nuclear programme has been passed to subsequent ruling elites regardless of what side of the political spectrum they come from. The lack of popular debate on the topic and the resulting policy of opacity has entrenched the decision makers' belief that proliferation and the nuclear option as a last resort is a necessary part of Israeli defence. The consequence of changing this policy would be seen as detrimental to Israeli's security.

For Israel, supporting the enforcement of the regime on to other states is a way of strengthening its security by ensuring that it maintains a nuclear monopoly in the Middle East. Israel wants a high degree of openness and transparency applied to other state's nuclear programmes, especially those that it sees as potential threats, but resists any attempt to have the same standards imposed on itself.

Iran on the other hand is outwardly trying to convince the international community that it is not interested in nuclear weapon proliferation. It presents itself as having been persuaded to embrace the non-proliferation norm and that it is only wants

\footnotetext{
${ }^{99}$ SM Hersh, The Samson Option: Israel's Nuclear Arsenal and American Foreign Policy (Random House Inc, 1991). Pgs 179-180.
} 
nuclear power. A 2005 fatwa issued by Ayatollah Khamenei which banned nuclear weapons in Iran has regularly been used to reinforce this view. ${ }^{100}$ It is the international community that does not believe this to be the case because the evidence does not support Iran's claims. ${ }^{101}$ Iran's sometimes antagonistic and often contradictory behaviour towards the IAEA as well as those who are trying to use diplomacy to resolve the issue reinforces a general disbelief in Iran's claims. The result is that the international community wants to be able to ensure that what Iran is actually saying is in fact the case. This could occur with IAEA monitoring all of Iran's nuclear facilities and not allowing full cycle reprocessing to occur. Iran has been persuaded that it requires nuclear power and this has been internalised by its leaders and accepted by the international community. It is the potential linking of this programme to nuclear weapon development that is the issue.

Israel has clearly not been persuaded to conform to the non-proliferation norm, in fact they are the opposite, while Iran is trying to convince a very sceptical international community that it has, even while much of the evidence does not support this claim. The result of the high degree of secrecy that surrounds the nuclear programmes in both countries is that there is no effective voice of dissent. In the cases of Sweden and Japan it was the role of domestic supporters of the nonproliferation norm that played a critical role in influencing the decision makers not to proliferate. This was the case even though there was strong support for proliferation by elements of the elite.

Identification as a rationale for forbearance is the existence of a hegemonic supporter; one that Iran or Israel would want to follow or is in the habit of following. The US is the only state that could be considered to fulfil this role for Israel. It is the US that has given tacit approval to Israel for its nuclear programme. The US has not put pressure on Israel to sign the NPT as long as it maintains its policy of opacity.

\footnotetext{
${ }^{100}$ Margulies, Nuclear Nonproliferation.Pg 88.

${ }^{101}$ Delpech, Iran and the Bomb: The Abdication of International Responsibility. Is a very detailed account of the evidence against Iran. Delpech is the director of strategic studies at the French Atomic Energy Commission (CEA) since 1997. She is also a researcher with CERI, commissioner with the United Nations Monitoring, Verification, and Inspection Commission, and international adviser to the International Committee of the Red Cross.
} 
And, that it upholds its promise to not be the first state to "introduce" nuclear weapons into the Middle East. The relationship between the US and Israel is unique, complicated and contradictory all at the same time. The US has supplied Israel with conventional arms since soon after its creation. Israel is portrayed in the US as both the victim in the Israeli- Arab conflict, and a small country surrounded by enemies that want to destroy it because they question its legitimacy. It is because of this that the US believes it is supporting the underdog. The existence of these threats has resulted in Israel believing it is justified in both defending itself, which is a right of all states, and also in deterring future invasions through the possession of nuclear weapons.

Israel emphasises that it is the only democracy in the Middle East and as a result is a natural ally of the west because of their shared values. ${ }^{102}$ Smooha's writing on ethnic democracies which I have explained in my case study is a very different form of democracy, (with clear parallels to apartheid) as opposed liberal democracies which are found in the west. These distinctions are down played by Israel's elites and if required to be justified are done so as being a necessary consequence of Israel's security situation. The strong linkages to expatriate Jewish communities in the west generally, but in the US in particular, are another important element of the relationship. These linkages allow further voices to be heard outside as well as inside of official diplomatic channels.

Mearsheimer and Walt's book "The Israel Lobby and US Foreign Policy" became very controversial for its attempts to explain this relationship. ${ }^{103}$ Their premise was that the US Israeli relationship was actually detrimental to US foreign interests in the Middle East and its own national security. They argue that because of the success of the influential "Israel lobby" subsequent administrations have continued to support Israel even when doing so went against US national interests. The US is the only hegemonic supporter that Israel actively listens to or could be made to listen to. If

\footnotetext{
${ }^{102}$ Bahgat, "Nuclear Proliferation in the Middle East: Iran and Israel." Pg 36-37.

${ }^{103} \mathrm{JJ}$ Mearsheimer and and SM Walt, The Israel Lobby and Us Foreign Policy (Farrar Straus Giroux, 2007).
} 
the US put economic sanctions on Israel and/or stopped military aid in an attempt to make it comply with the non-proliferation norm, Israel would have to listen. The US is the only state that is in a position to do this. Whether it would work or not is another issue. The UN and other international institutions have not been effective in countering or reigning in Israel's proliferation to date. The US, as one of the P-5, has used its power of veto to protect Israel at the UNSC in the past.

Iran has no hegemonic supporter at a state level. It has closely watched what has happened to other countries as they have developed their nuclear programmes (DPRK, Pakistan and India) and learnt from their very different experiences. This is, however, a very different kind of relationship from that of a hegemonic supporter. It is the international community as a whole that Iran focuses on and it is this that could be thought of as its closest thing to a hegemonic supporter. Iran has put a concerted effort into increasing its standing in the eyes of the international community and dispelling its reputation as an 'outlaw', 'pariah' or 'rogue' state. Because the international community is not a consistent or homogeneous ally it cannot fulfil the role required to make identification a plausible outcome. Iran aligns itself only with causes in the Middle East, not specific states. It sees itself as a potential leader in the region so has not allowed itself to be influenced by others. Because of its revolutionary beginnings, alignment with another state would be seen as contradicting its revolutionary principles and undermining its own legitimacy. Chubin describes it as;

"Normalisation and routinization of foreign policy necessitates jettisoning revolutionary claims, which are believed to be an intrinsic part of the regimes legitimacy. The revolutionary reflex competes with a detached pragmatism and often subverts it." ${ }^{104}$

This quote describes the complex and contradictory position of the Iranian regime and sheds some light on why the international community has had such difficulty in interacting with it and interpreting its often contradictory actions and statements.

${ }^{104}$ Chubin, Iran's Nuclear Ambitions. Pg 14. 
For identification the US is the only possible hegemonic supporter that Israel would listen to in support of the non-proliferation norm. The US has not been prescriptive in requesting Israel to support the non-proliferation norm. Instead it has supported the policy of opacity and never pushed Israel on the issue. The US rationale for not doing so has never been clearly defined and in reality its motives will be fluid, however there is much speculation on these. More pressing issues of US foreign policy have always managed to eclipse the issue. ${ }^{105}$ The US's approach to Israel has not gone unnoticed especially in the Middle East and remains a regularly referenced example of US foreign policy hypocrisy within the region. Iran does not have an hegemonic supporter and the closest one, by proxy, is the international community which is too fractured on the issue to act in that role. There is a clear connection between Iran and Israel and the US sheltering of the later adds to the Iranian resentment of the way it feels it is mistreated.

An acceptance of a norm as a result of social conformity occurs when the state's preference does not change, but their actions do, as a result of the desire to minimise the cost or maximise the benefit from following the norm. Israel, not following the norm, has had the reverse effect. The deterrent that has been achieved from proliferation has improved its security situation in the eyes of the decision makers. Domestically there has been no direct political cost to the decision makers for the decision to proliferate, which is largely a result of the taboo around even discussing it. Internationally, as discussed above there has also been minimal, if any, cost associated with this which is the result of the US's tacit approval. Because Israel has never signed the NPT, it's not breaking any laws (it is rejecting norms) with its possession of nuclear weapons. The majority of the members of the international community does not even raise the issue now largely because of Israel's relationship with the US. States within the international community that do raise it never get sufficient support to bring it to the forefront of international debate as there are always more 'pressing' issues to focus on. Alternatively Israel is presented as a special case and because it is the only democracy in the region if

\footnotetext{
${ }^{105}$ The Cold War, Iraq, DPRK, economic crisis etc.
} 
nothing else they are seen as being more trustworthy and hence pseudo-acceptable proliferators. ${ }^{106}$

Iran's cost benefit calculations are more subtle and require unpacking. Domestically nuclear power is seen as a means of improving the economy. The way in which Iran's nuclear programme has developed has been decided by the elite to include full cycle reprocessing which opens the door to proliferation. This has been sold domestically as the best option because it provides self sufficiency and thus does not rely on foreign support, which is something the Iranians know from experience can be withdrawn. Iran still needs to import the raw uranium but this is not emphasised domestically. Internationally there is great reluctance to allow Iran the full cycle option. Thus the cost benefit analysis for Iran hinges on how badly it wants the capability and whether it will accept the conditions dictated by the nonproliferation regime in order to get it. The evidence all supports an answer of very badly to the first question and a question mark for the second. The cost to Iran in the international social environment of breaking with the non-proliferation regime would be very high, even unacceptable. Further, sanctions on a country that relies on oil and gas exports for a large part of its revenue would be debilitating. The world's increasing demand for the same oil and gas would make this an action of last resort, if an option at all due to its potential impact on the world's economy.

Ideally the international community would like to see Iran persuaded to support the non-proliferation norm because if this was the case there could be a compromise on Iran's demand for the full cycle option. Genuine persuasion would be hard to achieve without strong internal support from non-proliferation norm supporters as was the case in Japan and Sweden. It was achieved in Egypt according to Rublee's findings because of the way in which Nasser reconceptualised security, accepting that diplomatic pressure against Israel was a powerful way to deal with an enemy. ${ }^{107}$ Iran does not currently have the same high international or regional standing that Egypt does, which it got, in part because of its decision to forgo the

\footnotetext{
${ }^{106}$ Bahgat, "Nuclear Proliferation in the Middle East: Iran and Israel." Pg 36-37.

${ }^{107}$ Rublee, Nonproliferation Norms: Why States Choose Nuclear Restraint. Pg 145.
} 
nuclear option. Nasser made the decision against the wishes of a strong internal pro-proliferation group of elites. ${ }^{108}$

The nature of Iran's revolutionary regime makes this type of decision difficult while still appearing to remain faithful to revolutionary ideals. The cost benefit analysis is most powerful because Iran cannot afford to be a self imposed outsider and maintain and increase the standard of living expected by the Iranians. The emergence of an existential threat as was the case in the First Gulf War with Iraq could change this but this, is considered unlikely to eventuate in the current climate. $^{109}$

Recently the international community has watched how Iran has dealt with dissent over the outcome of the 2009 presidential elections with most hoping that political change would come from within. Political change is the only likely way in which Iran will effectively be persuaded to support the non-proliferation norm in a manner that would be acceptable to the non-proliferation regime. In a similar way to that of a state's move to democracy, the most powerful force for this kind of large change has to come from within. ${ }^{110}$

Iran is watching and learning from the DPRK's experience and although some key decision makers clearly want nuclear weapons it is not at any cost. Acceptance of the non-proliferation norm under Rublee's social conformity label is a conceivable outcome for Iran although it is far from assured at present. Iran is most suited to the social conformity option because of its domestic pressures as well as the globally interconnected nature of its economy. The international community would need to define what exactly Iran needs to conform to and remain consistent in its demands

\footnotetext{
108 Ibid. Pgs 140-146. Gives an overview of the internal debates and the decision making process that lead to Nasser's decision not to proliferate, and Sadat's subsequent support for the same approach. ${ }^{109}$ The concurrent wars in Iraq and Afghanistan has stretched resources too thin and even Israel which regularly threatens to attack Iran's nuclear instalments could not unilaterally invade a country it does not border because of its limited strategic lift capability.

${ }^{110}$ A Karatnycky and P Ackerman, How Freedom Is Won: From Civic Resistance to Durable Democracy (Freedom House, 2005). Is a study of how states move from differing forms of political governance to democracy the only constant found from the research was that the pressure to democratise had to come from within a country if it was to be effective in making a transformation.
} 
for this to be the case. It is the inconsistency of the international community that is playing into the hands of the Iranian elites that want to proliferate. It is the fear, which is best articulated by the realist view which see it simply as a stepping stone to proliferation, which makes social conformity acceptance difficult. The belief is that Iran will play the game of nuclear hedging. Once it gets the required technology it will then leave the NPT and pursue its proliferation aspirations.

Germany is an interesting case study of Rublee's because, while remaining a nonproliferator, its reasoning for doing so changed. Originally it was social conformity through pressure from the US in the post World War II environment, but over time as this was internalised by the population and the ruling elites. The result was that both the elites and the general population was persuaded that non-proliferation was the best option. It has recently decided against any further nuclear power programmes and adopted a policy with the long term goal of becoming nuclear power free as well proliferation free. This decision has been made taking into consideration Germany's proficiency at building and exporting nuclear power reactors and associated technology. This example emphasises the fluid nature of norm conformity and the changing rationale that can lie behind it.

Israel's situation is different. Social conformity would only be an outcome if persuasion or identification were to play a bigger role in the decision making process. For persuasion to be a possibility there would have to be an initial domestic debate on the issue. Some of the secrecy surrounding the decision making processes would also have to be removed. This would necessitate the end of the Israeli policy of opacity. Israel would need to join India and Pakistan as non NPT signatories who possess nuclear weapons. The result of doing this would be the public confirmation of what everyone already knows i.e. that Israel is a nuclear weapon state. Because it is already public knowledge it would be impossible to argue that this would decrease Israel's security. Israeli nuclear weapon capability has only worked as a deterrent because Israel's enemies knew it existed, so confirming this is unlikely to change anything. 
This seemingly small action will likely have the effect of reinforcing the nonproliferation norm by removing the grey area in the middle, which is what Israel has become because of its policy of opacity. Identification could also play a role. The US is the only state that could use pressure on Israel to end the policy of opacity. The sequence in which either of these events happen will have a definite impact on either domestic politics or US Israeli relations and this could be either positive or negative depending on how it is presented. ${ }^{111}$ It could be presented to the Iranians and the world by the US as an example of how they are making Israel more accountable or conversely by the Israeli's as a gesture to Iran, although the later seems highly unlikely. Domestically it could be presented as an example of how the country has grown out of the opacity policy and into a better light internationally on the issue or that it wants to make these decisions more democratic. The options are as vast as the imagination of decision makers. The non-proliferation norm and the regime are clearly effective; the vast majority of states that follow it support this view. Why is it not working in the cases of Iran and Israel? I will now look at some external factors that could possibly be diluting the norm or overshadowing the norm.

\section{External influences for nuclear proliferation}

The main external influences I have identified are; economic considerations, access to technology, specific security situations, the processes by which the states were constructed and key decision makers. I will look at the impact that these influences have had on Rublee and my case studies to see if the offer alternative justifications for proliferation.

The high economic cost of nuclear programmes, which was a big factor for Egypt, has not been a real consideration for either Iran or Israel. Iran with its huge oil and gas reserves has access to large quantities of foreign currency. Nuclear power is

${ }^{111}$ Cohen, "The Bomb That Never Is." Pg 23. 
seen as a way of being able to export more of these reserves and earn more foreign currency.

Israel has one of the highest GDP's in the Middle East and is considered economically successful. The secrecy surrounding Israel's nuclear programme makes it difficult to find out how much it has cost and how it was financed. The initial funding was kept separate from the official budget to maintain secrecy and to avoid debate over this expenditure with other arms of government. According to Cohen's research half of the 80 million (this is in 1960 US dollars) required to build the Dimona reactor was raised through private donations from around the world. ${ }^{112}$ It is fair to conclude that although the cost was great its perceived importance meant funding was found as and when it was required.

Access to technology and the associated expertise was a major stumbling block for both Egypt and Libya in their quest for nuclear weapons. In the case of Israel, the simple answer was that this was not an issue. Israel sent students to western counties to be trained and they were allowed open access to France's facilities as part of its assistance in the building of Dimona. Immigrating Jewish nuclear scientists from the former USSR were also employed by the nuclear programme. ${ }^{113}$ Today Israel has a well established and technologically advanced nuclear programme which has limited the attractiveness of the NPT as a means of accessing technology. The access to technology and personnel for peaceful nuclear purposes as laid out in the NPT is used as a carrot for state compliance. This is totally redundant because Israel already has all the required capability so has nothing to gain. ${ }^{114}$

In the case of Iran, the programme was started by the Shah who also sent young scientists to the west to study. This stopped after the revolution and in more recent years Iran has had to look to China and Russia for the sale of nuclear power related technology as well as the training of its people. Neither of these countries wants

\footnotetext{
112 - - Israel and the Bomb. Pg 70.

${ }^{113} \mathrm{Ibid}$. gives full details of when this occurred.

${ }^{114}$ Kadhim, "The future of nuclear weapons in the Middle East". Pg 150. in Lavoy, Nuclear Weapons Proliferation in the Next Decade.
} 
Iran to have nuclear weapons so this limits what they are willing to sell them. ${ }^{115}$ Iran has a limited relationship with the DPRK and evidence supports the view that they share nuclear information. This includes as previously indicated Iranian scientists being present at the DPRK long range (nuclear warhead capable) missile launch in $2006 .{ }^{116}$ Access or more correctly the lack of access to the required technology has definitely affected the speed at which Iran has been able to carry out its nuclear programme. The international community has actively and with some degree of success tried to make this as difficult as possible for Iran. This tactic worked partially in the past with Egypt and Libya both of whom accepted the non-proliferation norm. Neither of these countries had progressed very far and both were more focused on nuclear weapons acquisition than nuclear power production. This made their situation more black and white with regards to the non-proliferation regime.

State's security has been used as the justification for the proliferation of nuclear weapons and the Cold War arm's race is the most dramatic example of this. The argument goes that the deterrent effect achieved from the possession of nuclear weapons will prevent a non nuclear armed enemy from acts of aggression against one that is nuclear armed. The imbalance will work in favour of the state that is nuclear armed. To counter this, a potential aggressor will also need to be armed with nuclear weapons to counter the other state's nuclear weapons. This then escalated to the requirement for a second strike capability, that is, one which is protected from the impact of a first strike (either submerged in a submarine or protected deep underground in protective bunkers) and allows the state to retaliate. One quickly sees that this strategy can go on forever and is limited only by finance. This sort of escalation will occur only if both states have nuclear weapons, otherwise the initial imbalance remains. It is the deterrent effect of nuclear weapons that some, mainly from the realist school, believe, will lead to a more stable international environment. By raising the stake of the consequence of state

\footnotetext{
${ }^{115}$ Margulies, Nuclear Nonproliferation. Pgs 87-88 outlines the technology transfer relationship. ${ }^{116}$ Delpech, Iran and the Bomb: The Abdication of International Responsibility. Pg 73-74.
} 
aggression to the level nuclear weapons do, it will result in a decrease in this aggression because the consequences are too great. ${ }^{117}$

Israel's nuclear deterrent is thought to be effective by the decision makers because it has a monopoly on this deterrent in the region. Any change to this is believed to have the consequence of diminishing the effectiveness of the deterrent which will result in a worsening of Israeli's security. This whole argument is based on a very narrow definition of security, one based solely on military capability. The state of Israel was literally born on the battlefield and over the first 25 years of its existence it fought in four wars with its immediate neighbours. The last of these was the Yom Kippur War of 1973. Since that time its relationship with its neighbours has actually improved. Egypt and Jordan and to a lesser extent Syria and Lebanon have, as a result of military defeat, chosen diplomacy over the battlefield as a way to work through their grievances. The close geographical proximity of these old enemies makes the use of nuclear weapons as being viable only as an option of last resort.

The major security issue facing Israel comes from Palestinians dissatisfied with the failure of the two state settlement processes. A nuclear Israel has no deterrent effect on this situation. Iraq was seen as a threat and has even fired Scud missiles into Tel Aviv in the past. Iraq has since been removed from the equation, for the interim.

Iran is one country that refuses to acknowledge Israel's legitimacy as a state and its President Ahmadinejad, has called for Israel to be "wiped of the map". ${ }^{118}$ This and other highly inflammatory remarks ensure that Israel watches Iran very closely. Iran has a Jewish minority and they have a member of parliament to represent them. Most of this sort of rhetoric although highly disturbing, is an emotive way of saying they support the Palestinian people's struggle for a two state settlement and feel that the Palestinians are being unfairly treated. Toned down versions of the same

\footnotetext{
${ }^{117}$ This is Waltz central proposition in; Sagan and Waltz, The Spread of Nuclear Weapons: A Debate Renewed.

${ }^{118}$ Margulies, Nuclear Nonproliferation. Pg 90.
} 
sentiment can be heard in almost all Middle Eastern capitals. ${ }^{119}$ If the Israelis could agree upon a workable two state settlement option many of the external threats would dissipate. Israel and Iran have no direct dispute with each other. Instead they each use the other as a focal point to draw attention away from themselves and their own actions. ${ }^{120}$

Israel has mitigated its complex security situation, in part, by maintaining an asymmetrical nuclear weapon capability within the Middle East. It is this monopoly that Israel is focused on maintaining. Iran's greatest security challenge comes from the US and the presence of US troops on three of its borders. ${ }^{121}$ Some of Iran's revolutionary identity comes from its rejection of US hegemony. The decision makers reinforce their authority and the legitimacy of the revolutionary regime by emphasising the double standards in the way the US operates. The close proximity of the US military makes these decision makers nervous, which has resulted in them taking an even more confrontational and antagonistic position against the US.

Assessing Iran's security situation has led some to the conclusion that pursuing nuclear weapons is a rational way forward. Because of this the fact that Iran does not possess nuclear weapons should be interpreted as a sign of its self restraint. ${ }^{122}$ In Iran and Israel their security environment has played and continues to play an important role this however is only part of the picture.

In the case of Israel the key element is that the state was created out of the experience of the holocaust which itself was the culmination of thousands of years of differing forms of persecution in much of the world. Israel is seen as the one place that Jewish people can go to in order to be safe from persecution. In reaction to the horror of the holocaust the decision makers emphasised the need to be able to ensure that it could never happen again and made this a central part of the

\footnotetext{
119 Ibid. Pg 90-91.

${ }^{120}$ Bahgat, "Nuclear Proliferation in the Middle East: Iran and Israel." Pg 29-30.

${ }^{121}$ Iraq, Afghanistan and Turkey.

122 Kibaroglu, "Good for the Shah, Banned for the Mullahs: The West and Iran's Quest for Nuclear Power." Pgs 219-222. And Z Brzezinski, RM Gates, and S Maloney, Iran: Time for a New Approach (Council on Foreign Relations, 2004). Pg 22.
} 
state's identity. Hand in hand with this has been the emphasis on Jewish Israel's achieving this themselves, and by never having to rely on other states to assist. This has resulted in a very pragmatic approach to interactions with international institutions. They are viewed as being useful to a point, but there is a definite group of issues on which Israel will not compromise. In Iran's case this is not so important. I have already described the effects of its revolutionary origins on its decision making process and the difficult balancing act that the rulers must play to both maintain legitimacy internally as well as relating to others internationally. This conflict also plays out domestically in the attempt to balance their great Persian history which was pre-Islamic with Islamic revolutionary ideals.

The role that a handful of elites have played in the nuclear decisions of both countries is the final area I will discuss. The autocratic nature of the decision making process in both countries worked against both the non-proliferation norms and the associated regime's effectiveness. The influence of both comes from discussion, openness and dialogue all of which have been limited in these two cases.

Libya attempted to acquire nuclear weapons over a long period of time and then reversed its policy. Both decisions were made by the same authoritarian leader, Mu'ammar al-Qadhafi which makes it unique. In 2003 Qadhafi decided that it was in Libya's best interest to accept the non-proliferation regime. The decision to do so was made in part by the fear that Libya could be the next US target after Iraq. This decision was also made knowing that it would have the flow on effect of improving the economy, through the lifting of sanctions, as well as elevating his and Libya's standing within the international community. In this example the decision by Libya to align itself with the existing international non-proliferation norm strengthened its security situation, improved its economic situation and elevated its status internationally. ${ }^{123}$ The small group of decision makers in each country has made the ability of the norms to influence their decisions more difficult but not impossible as Qadhafi has shown.

${ }^{123}$ Rublee, Nonproliferation Norms: Why States Choose Nuclear Restraint. Pgs 151-169. 
Economic considerations, access to technology, specific security situations, state construction and key decision makers have all played parts of the proliferation in Iran and Israel. Collectively they have weakened the non-proliferation regime and made each state's elite less inclined to accept the associated norms. These however are not enough to explain Iran and Israel's proliferation by themselves. The nonproliferation regime has evolved over time. It is fluid enough to incorporate both countries as long as it is applied consistently. These external influences have played a part however they do not offer enough to explain proliferation. For every external influence that could be used to explain proliferation an example of a state can be found where non-proliferation has occurred. To treat state proliferation as the make or break of the whole non-proliferation regime is to deny its fluid nature and accept the 'slippery slope' analogy.

The constructivist analysis of Iran and Israel's proliferation clearly identifies possible policy approaches that would strengthen the non-proliferation norm. For example removing US import/export controls on Iran in favour of imposing IAEA guidelines for the movement of nuclear materials in and within Iran. Actions such as this reinforce the regime and its norms in an inclusive and standardised manner and help to remove Iran's perception of persecution at the hands of the US. By actions such as this the norm is dissected, which facilitates a deeper understanding of the influence norms have and how they are received and perceived by states. By understanding this process the strengths and weaknesses of the norms are identified and can be compensated for. One of the key strengths of the norm is that it extrapolates above the level of the state into that of the international community. In doing this a more even handed approach can be taken than would ever be possible if the issue was being dealt with just between two states, as the US unilateral import/export restrictions have been.

In the case of Iran without political change the only possible outcome will be social conformity. For this to happen, the international community must be unified in opposing (or at least deferring as long as possible) Iran's ownership of a full cycle 
reprocessing capability. Sanctions, if required, should be focused on punishing the elites not the general population. If political change occurs in Iran then genuine persuasion against the possession in support of the norms of nuclear weapons could be possible. This would occur if the result of the political change was either, a more democratic system, or one that was less confrontational like Libya has become.

For Israel any change to their current policy of opacity would either have to come from within or from pressure from the US. The opening up of domestic debate on the nuclear issue would allow alternative points of view to be heard. This would be unlikely to result in any quick change to Israel's nuclear position however it would the first step in doing so. Alternatively, the US could apply pressure to Israel to do the same. The outcome would be the same, what would change would be either Israel's domestic politics or US/Israeli relations. These changes would either see an increase in the role of persuasion or identification in Israeli decision making. One or both of these changes needs to occur before social conformity could play a role. 


\section{Conclusion}

The non-proliferation regime and its norms have been the most successful influences on deterring states from proliferating nuclear weapons. The NPT, a central component of this is the most successful arms control treaty in world history. Rublee used a constructivist approach to explain why states have shown nuclear restraint in support of the regime and its norms. I have attempted to use the same approach to see what it can tell us about states that don't conform to these norms and proliferate nuclear weapons. Rublee used Germany, Egypt, Libya, Sweden and Japan as case studies of states that have shown restraint. I have used Iran and Israel as my case studies for states that are not or have not shown restraint. Iran is in the process of covertly developing nuclear weapons, and is doing so by disguising it true motives behind an constantly changing interpretation of the NPT. Israel has had nuclear weapons for over 40 years yet still refused to officially acknowledge this fact. By doing this they are rejecting and undermining the nonproliferation norms, which makes it harder to enforce it on other states without appearing hypocritical.

A State's decision to proliferate or not can and does change. Because this is the case it is important to know why states make the decisions that they do in order to influence a change of outcome. It is important to understand the role that norms play in shaping state this decision making. Constructivism breaks up the process by which norms are received by states and accepted or rejected into transmission, processing and potency. The result of breaking it down to this level is that as things change we can see the impacts they will have on these norms and attempt to counter any negative outcomes.

The three state outcomes of persuasion, Identification and social conformity allow us to explore how committed to the norms different states are. In the cases of Iran and Israel they allow us to see what would have to change in order for one or more of these to become an outcome for the two states. The way in which the norm has been received by the two countries is different. Iran gets an inconsistent set of 
expectations from the international community while Israel gets almost no expectations placed upon it by the very same international community. On the surface it appears that this is the case because Israel is not a NPT signatory but in reality it is their special relationship with the US and the protection from the scrutiny of the international community that this brings on the nuclear issue. The NPT is designed as an unequal treaty which separates the nuclear weapon haves from the have-nots. The countries that have signed it have had to accept this. The position Israel has taken is one that is unique in that its nuclear status in undeclared. Israel has been allowed to gain the benefits from the wider regime without having to submit to any of its conditions. By looking at its specific situation through the constructivist framework this has been made very clear, as has the negative impacts of this on the regime and norm. This insight would have been difficult, if to acquire from either a realist or neo-liberal institutionalist perspective only.

For Iran the norm has been ineffectual because it has been transmitted inconsistently from a fractured international community. If this was to happen to almost any other state they would have another country or group of countries who could assist them with defining what is best to do. Iran is not in this situation. This is exacerbated by the Islamic and revolutionary nature of the state. In the west, the separation of religion and the state is seen as a fundamental part of what is to be modern, and revolutions are seen as ways of achieving this separation. Therefore the Iranian revolution did the structural opposite, of what the west defines as being required to being a modern state. This was done while simultaneously possessing all of the trappings which are expected of a modern state. The difficulty countries have in dealing with Iran has resulted in conflicting expectations from these countries being placed on Iran. The elite have taken advantage of this to pursue their proliferation ambitions within the confusion. Iran's difficult relationship with the US has become a tool to divide the international community, much of which is unhappy with how Iraq and Afghanistan are working out.

My study has focused on the non-proliferation norm however this constructivist approach could be used to examine other international regimes. Combining this 
with realist and neo-liberal institutionalist explanations builds a more rounded explanation for explaining proliferation and non-proliferation. By deconstructing the why and how it is much easier to ascertain how to change undesired outcomes. The constructivist approach acknowledges the ability of states to change position over time, and lays out a framework explaining why this is so.

There exists a grey area between nuclear power generation and nuclear weapon development and it is here that role of the non-proliferation norms are most important. By understanding how norms operate a better explanation for proliferation as well as non-proliferation can be provided. Rublee's framework has shown itself to be robust enough to assist in the explanation of state nonconformity to non-proliferation norms. 


\section{Bibliography}

Ackerman, P., and A. Karatnycky. "How Freedom Is Won: From Civic Resistance to Durable Democracy." New York, Freedom House (2005).

Albright, D. "When Could Iran Get the Bomb?" Bulletin of the Atomic Scientists 62, no. 4 (2006): 26-33.

Bahgat, G. "Nuclear Proliferation in the Middle East: Iran and Israel." Contemporary Security Policy 26, no. 1 (2005): 25-43.

- - - "Nuclear Proliferation: The Islamic Republic of Iran." International Studies Perspectives 7, no. 2 (2006): 124-36.

Bailey, KC. Strengthening Nuclear Nonproliferation: Westview Press, 1993.

Bellany, I. Curbing the Spread of Nuclear Weapons: Manchester University Press, 2005.

Betts, R.K. "The Osirak Fallacy: If the Strike on Osirak Failed to Turn Back the Clock on Saddam's Nuclear Program, Why Would One Work for Iran?" National Interest 83, (2006): 22.

Black, I. Israel's Secret Wars: A History of Israel's Intelligence Services: Grove Press, 1994. Blanchard, C.M. "Islam: Sunnis and Shiites." 2006.

Blix, H. "Weapons of Terror: Freeing the World of Nuclear, Biological and Chemical Arms." In Report of the Weapons of Mass Destruction Commission: Weapons of Mass Destruction Commission

2006.

Brzezinski, Z., R.M. Gates, and S. Maloney. Iran: Time for a New Approach: Report of an Independent Task Force Sponsored by the Council on Foreign Relations: Council on Foreign Relations Press, 2004.

Bunn, G. "The Nuclear Nonproliferation Treaty: History and Current Problems." Arms Control Today 33, no. 10 (2003): 4-10.

Chubin, S. Iran's Nuclear Ambitions: Carnegie Endowment for International Peace, 2006.

Cirincione, J, R Gottemoeller, and J Wolfsthal. "A New Non-Proliferation Strategy." SAIS REVIEW 25, no. 2 (2005): 157.

Cirincione, J. "Stop the Fuel Cycle, I Want to Get Off." Fletcher F. World Aff. 30, (2006): 27.

Cohen, A. "The Bomb That Never Is." Bulletin of the Atomic Scientists 56, no. 3 (2000): 22-23.

- - - Israel and the Bomb: Columbia Univ Pr, 1998.

Cohen, A, and W Burr. "Israel Crosses the Threshold." Bulletin of the Atomic Scientists 62, no. 3 (2006): 22-30.

Cohen, Yoel. The Whistleblower of Dimona: Israel, Vanunu, and the Bomb.: Holmes \& Meier Publishers, 2003.

Colin Keating, Executive Director. "Cross-Cutting Report on the Security Council's Role in Disarmament and Arms Control: Nuclear Weapons, Non-Proliferation and Other Weapons of Mass Destruction.": Security Council Report, 2009.

DDA, United Nations Department for Disarmament Affairs - UN. "Verifying Non-Proliferation \& Disarmament Agreements Today : Panel Discussion, United Nations, New York, 20 October 2005." Geneva: United Nations, 2005.

Delpech, T. Iran and the Bomb: The Abdication of International Responsibility. Translated by From French by Ros Schwartz: C. Hurst \& Co. London, 2009. 
Dhanapala, J, and R Rydell. Multilateral Diplomacy and the Npt: An Insider's Account: United Nations Pubns, 2005.

El-Khawas, M.A. "Iran's Nuclear Controversy: Prospects for a Diplomatic Solution." Mediterranean quarterly 16, no. 4 (2005): 20-41.

Energy, US Department of. "Country Analysis Brief: Iran." 14: Energy Information Administration 2010.

_- - "World Oil Transit Chokepoints." Energy Information Administration 2010.

Fierke, KM. Critical Approaches to International Security: Polity Press, 2007.

Fitzpatrick, M. "Iran and North Korea: The Proliferation Nexus." Survival 48, no. 1 (2006): 6180.

Graham, T. Disarmament Sketches: Three Decades of Arms Control and International Law: University of Washington Press, 2002.

Hashmi, S.H. Ethics and Weapons of Mass Destruction: Religious and Secular Perspectives: Cambridge Univ Pr, 2004.

Hersh, S.M. The Samson Option: Israel's Nuclear Arsenal and American Foreign Policy: Random House New York, 1991.

Hunt, J J B. "Pm Office." edited by Joint intelligence Commitee. London: National Archive UK, 1961.

Johnston, A.I. "Treating International Institutions as Social Environments." International Studies Quarterly 45, no. 4 (2001): 487-515.

Karpin, M. The Bomb in the Basement: How Israel Went Nuclear and What That Means for the World: Simon \& Schuster, 2007.

Keohane, RO, and JS Nye Jr. "Governance in a Globalizing World." Power and Governance in a Partially Globalized World, Routledge, Editor (2000): 193-218.

Kibaroglu, M. "Good for the Shah, Banned for the Mullahs: The West and Iran's Quest for Nuclear Power." The Middle East Journal 60, no. 2 (2006): 207-32.

Kile, S.N. "Europe and Iran: Perspectives on Non-Proliferation." A SIPRI Publication, 2005.

Kissinger, Henry. "National Security Memorandum 292 Us - Iran Nuclear Cooperation ", edited by National Security Council. Washington DC, 1975.

Knief, R.A. Nuclear Engineering: Theory and Technology of Commercial Nuclear Power: Taylor \& Francis, 1992.

Krasner, S.D. "Structural Causes and Regime Consequences: Regimes as Intervening Variables." International organization 36, no. 2 (1982): 185-205.

Lavoy, P. Nuclear Weapons Proliferation in the Next Decade: Routledge, 2007.

Leigh, David. "How the Uk Gave Israel the Bomb." The Guardian 2005.

Levi, MA, and ME O'Hanlon. The Future of Arms Control: Brookings Institution Press, 2005.

Levite, A.E. "Never Say Never Again: Nuclear Reversal Revisited." International Security 27, no. 3 (2003): 59-88.

Lodgaard, Morten Bremer Maerli and Sverre. Nuclear Proliferation and International Security, Routledge Global Security Studies 1: Routledge, 2007.

Margulies, P., and S. Squassoni. Nuclear Nonproliferation: Facts on File, 2008.

Mbembe, A. "Necropolitics." Public culture 15, no. 1 (2003): 11-40.

Mearsheimer, JJ, and SM Walt. The Israel Lobby and Us Foreign Policy: Farrar Straus Giroux, 2007.

Newman, E, R Thakur, and J Triman. Multilateralism under Challenge: Power, International Order, and Structural Change: United Nations University Press, 2006. 
Nye, J.S. The Paradox of American Power: Why the World's Only Superpower Can't Go It Alone: Oxford University Press, USA, 2003.

Nye, JS. Power in the Global Information Age: From Realism to Globalization: Routledge, 2004.

Price, R. "Nuclear Weapons Dont Kill People, Rogues Do." International Politics, 44 2, no. 3 (2007): 232-49.

Price, R. "A Genealogy of the Chemical Weapons Taboo." International organization 49, (1995): 73-73.

Raas, W., and A. Long. "Osirak Redux? Assessing Israeli Capabilities to Destroy Iranian Nuclear Facilities." International Security 31, no. 4 (2007): 7-33.

Rappert, B. Controlling the Weapons of War: Politics, Persuasion and the Prohibition of Inhumanity: Routledge, 2006.

Richmond, O.P. Peace in International Relations: Routledge, 2008.

Rublee, MR. "Egypt's Nuclear Weapons Program." The Nonproliferation Review 13, no. 3 (2006): 555-67.

- - - Nonproliferation Norms: Why States Choose Nuclear Restraint: Univ of Georgia Press, 2009.

- - - "Taking Stock of the Nuclear Nonproliferation Regime: Using Social Psychology to Understand Regime Effectiveness." International Studies Review 10, no. 3 (2008): 420-50.

Safeguards, I. "Stemming the Spread of Nuclear Weapons." IAEA Bulletin 43, no. 4 (2001): 12.

Sagan, S.D. "Why Do States Build Nuclear Weapons?: Three Models in Search of a Bomb." International Security 21, no. 3 (1996): 54-86.

Sagan, SD, and KN Waltz. The Spread of Nuclear Weapons: A Debate Renewed. 2nd updated from 1995 first edition ed: W. W. Norton \& Company, 2003.

Schneider, M. "The Permanent N Th Country Experiment Nuclear Weapons Proliferation in a Rapidly Changing World." Mycle Schneider International Consultant on Energy and Nuclear Policy, 2007.

Sharp, Jeremy M. "U.S. Foreign Aid to Israel." Congressional Research Service 7-5700 RL33222, (2009).

Sharp, M. edited by. "U.S. Foreign Aid to Israel.": Congressional Research Service, 2009.

Sidhu, Waheguru, and Ramesh Thakur. Arms Control after Iraq - Normative and Operational Challenges: UN University press, 2006.

Smooha, S. "The Model of Ethnic Democracy: Israel as a Jewish and Democratic State." Nations and Nationalism 8, no. 4 (2002): 475-503.

Squassoni, S. "Iran's Nuclear Program: Recent Developments." 2006.

Stalenheim, P., C. Perdomo, and E. Skons. "Military Spending and Armaments." SIPRI Annual report (2006).

Tannenwald, N. The Nuclear Taboo: The United States and the Non-Use of Nuclear Weapons since 1945. Vol. 87: Cambridge Univ Pr, 2007.

- - . "The Nuclear Taboo: The United States and the Normative Basis of Nuclear NonUse." International organization 53, no. 3 (1999): 433-68.

- - . "Stigmatizing the Bomb: Origins of the Nuclear Taboo." International Security 29, no. 4 (2005): 5-49.

Tannenwald, Nina. "Deciding Not to Join the Nuclear Club." The Nonproliferation Review 16, no. 3 (2009): 527 - 32. 
Thakur, Ramesh. War in Our Time - Reflections on Iraq, Terrorism and Weapons of Mass Destruction: United Nations University Press, 2007.

Treaty on the Non-Proliferation of Nuclear Weapons. 22 April 1970.

Ungerer, C, and M Hanson. The Politics of Nuclear Non-Proliferation: Allen \& Unwin in association with the Dept. of International Relations, RSPAS, St. Leonards, NSW, Australia, 2001.

Yearbook, SIPRI. "Stockholm: Stockholm International Peace Research Institute." 2009. 